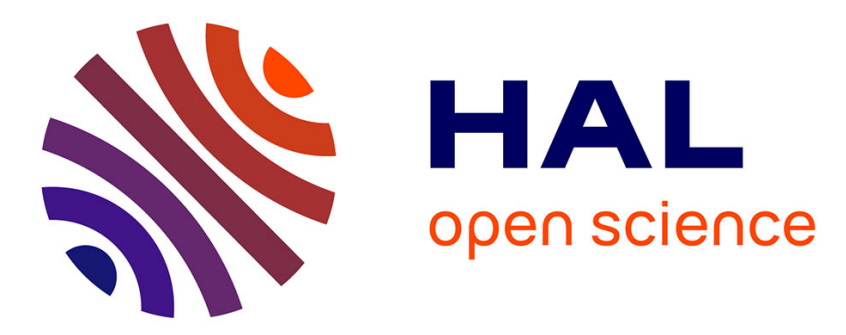

\title{
Intra-Household Coping Mechanisms in Hard Times : the Added Worker Effect in the 2001 Argentine Economic Crisis
}

\author{
Laurine Martinoty
}

\section{- To cite this version:}

Laurine Martinoty. Intra-Household Coping Mechanisms in Hard Times: the Added Worker Effect in the 2001 Argentine Economic Crisis. 2015. halshs-01133388

\section{HAL Id: halshs-01133388 \\ https://shs.hal.science/halshs-01133388}

Preprint submitted on 19 Mar 2015

HAL is a multi-disciplinary open access archive for the deposit and dissemination of scientific research documents, whether they are published or not. The documents may come from teaching and research institutions in France or abroad, or from public or private research centers.
L'archive ouverte pluridisciplinaire HAL, est destinée au dépôt et à la diffusion de documents scientifiques de niveau recherche, publiés ou non, émanant des établissements d'enseignement et de recherche français ou étrangers, des laboratoires publics ou privés. 


\title{
GATE

UMR 5824

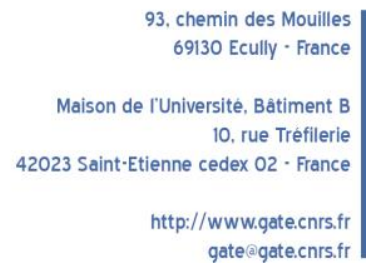

WP 1505 - March 2015

\section{Intra-Household Coping Mechanisms in Hard Times : the Added Worker Effect in the 2001 Argentine Economic Crisis}

\author{
Laurine Martinoty
}

\begin{abstract}
:
This paper shows that the added worker effect (AWE) plays an important role in coping against aggregate shocks, even in cases where the discouragement effect prevails at a macroeconomic scale. Using an Argentine panel dataset between 2000-2002, we instrument the endogenous variation in the labor market outcomes of household heads using the collapse of the Convertibility era as a natural experiment, and measure its causal impact on their spouses' labor supply decisions. Within this framework, we show that a woman whose husband experiences the average decline in income is 4.4 percentage points more likely to enter the labor market. Out of four new entrants, three work at least one hour weekly, and one even finds a full time job. Heterogeneous effects are in line with expectations, robustness checks support the validity of our empirical strategy, and our results are robust to various sensitivity tests.
\end{abstract}

\section{Keywords:}

Added worker effect, married women labor market participation, panel data, natural experiment, instrumental variable

JEL codes:

C33, D13, J22 


\title{
Intra-Household Coping Mechanisms in Hard Times : the Added Worker Effect in the 2001 Argentine Economic Crisis
}

\author{
Laurine Martinoty ${ }^{+}$
}

March 18, 2015

\begin{abstract}
This paper shows that the added worker effect (AWE) plays an important role in coping against aggregate shocks, even in cases where the discouragement effect prevails at a macroeconomic scale. Using an Argentine panel dataset between 2000-2002, we instrument the endogenous variation in the labor market outcomes of household heads using the collapse of the Convertibility era as a natural experiment, and measure its causal impact on their spouses' labor supply decisions. Within this framework, we show that a woman whose husband experiences the average decline in income is 4.4 percentage points more likely to enter the labor market. Out of four new entrants, three work at least one hour weekly, and one even finds a full time job. Heterogeneous effects are in line with expectations, robustness checks support the validity of our empirical strategy, and our results are robust to various sensitivity tests.
\end{abstract}

Keywords: added worker effect, married women labor market participation, panel data, natural experiment, instrumental variable

JEL: C33, D13, J22

+ Université de Lyon, Lyon, F-69007, France; CNRS, GATE Lyon Saint-Etienne, Ecully, F69130, France; Ecole Normale Supérieure de Lyon, Lyon, F-69007, France; Aix-Marseille University (Aix-Marseille School of Economics), CNRS-GREQAM and EHESS, F-13002, France ; Contact: martinoty@gate.cnrs.fr 


\section{Introduction}

Along her life cycle, an individual is repeatedly exposed to a wide variety of idiosyncratic shocks, like health or displacement shocks, as well as aggregate shocks, like economic turmoil, political conflicts, or climate change. These shocks may cause a transitory or permanent wealth loss. When information is imperfect and credit market are constrained, households cannot smooth their consumption along the life cycle. Shocks come at cost in terms of well-being, unless they develop original coping strategies.

The economic literature on coping strategies usually stresses out the distinction between ex ante and ex post risk coping mechanisms. Though response mechanisms vary greatly according to local specificities and types of shock, they can be summed up into three categories. Adjustment strategies consist in modifying consumption patterns, selling assets or allocating more time to home production. In Zimbabwe, individuals responded to drought by selling cattle in a consistent way with long term livestock accumulation objectives (Kinsey et al., 1998). During the 1998 financial crisis in Russia, middle and lower class households decreased their consumption of normal goods (Lokshin and Yemtsov, 2004). In the aftermath of the 2001 Argentine economic crisis, individuals allocated a larger amount of their leisure time to shopping activities, with the aim to track down information on available goods and best prices (McKenzie and Schargrodsky, 2011). Network strategies rely on the social capital accumulated by individuals. For instance, sharing a network with family or friends who migrated enables an individual to cash in remittances during hard times (Mohapatra et al., 2012), and also facilitates own migration. In Botswana, urban migrants keep their former rural network and assets as a safety net against uncertain urban prospects (Krueger, 1998). Informal insurance between households also allows for a monetary or non monetary redistribution, as in the case of US, where young actives move in and out of the parental home depending on labor market risks (Kaplan, 2012). Finally, active strategies regroup labor market oriented strategies, like double shift jobs, informal secondary occupation, or selling of home production. For example, in rural India, Kochar (1999) shows that individuals switch from farm to off-farm activities with climate shocks.

Clearly, household formation plays an important role in all coping responses against risks and shocks. Indeed, insurance is one of the traditional functions of marriage, in so far it allows for ex ante risk diversification. In addition, shock coping decisions taken at the intra-household level are de facto more flexible than the set of strategies available to a single individual, because households are assumed to pool their resources in time 
and income. ${ }^{2}$ This is particularly the case for market-oriented strategies. Indeed, single individuals can only increase their labor supply at the intensive margin. On the opposite, households can extend their labor supply by having one or more extra members entering the labor market. Taking its origin in Woytinsky (1940), the added worker effect hypothesis (henceforth AWE) states that in the eventuality of a shock on the primary earner in the household, secondary workers would enter the labor market as imperfect substitutes to smooth consumption profile at the household level.

In theory, assuming complete markets and perfect information, the AWE is expected to be small for two reasons. At the individual level, the first life cycle models show that the income reduction from a temporary shock is negligible in relation to lifetime income (Heckman and Macurdy, 1980). Intertemporal allocation of other members' time should thus not be too distorted by the transitory unemployment spell or income shock hitting the household head. Second, at the aggregate level, a discouraged worker effect should prevail over the added worker effect: even if spouses individually increase their labor market participation in response to a negative shock affecting the household head, the depressed economy is expected to drive even more spouses to withdraw from the labor market, the overall impact of the negative shock on additional workers' participation thus being negative.

However, in practice, the magnitude of the AWE depends on several factors, namely the availability of alternative strategies to smooth income loss; the degree of imperfection of markets for credit and liquidity constraint limiting access to consumption smoothing through borrowing (Bingley and Walker, 2001); the perception of unemployment shocks as a new information about negative lifetime income prospects (Dynarski and Sheffrin, 1987). Taking this uncertainty into account, Stephens (2002) extends the life cycle model of labor supply under uncertainty of MaCurdy (1985) to a two adult household, allowing for a substantial temporary added-worker effect to arise. Empirically, the literature testing the existence of this AWE reports mixed evidence. While early, seminal studies established that transitory shocks on husband's labor market outcomes have an impact on their spouse's labor supply, other studies failed to highlight any significant effect. Recent developments in the literature on AWE explain this inability to reach a consensus by several methodological issues, namely the differences in the definition of the AWE (or in the underlying labor supply model), and weaknesses in the identification strategy. Taking these flaws into account, the most recent studies tend to favor the AWE

\footnotetext{
${ }^{2}$ This income pooling hypothesis corresponds to a unitary conception of the household. Collective models have proven their empirical consistency and repeatedly rejected full income pooling (see e.g. Duflo and Udry (2004)). However, in this paper, we adopt a unitary framework. Sadly, our dataset does provide the necessary information to test the adequacy of the unitary model.
} 
hypothesis. Using panel data to investigate fluctuations in child labor and schooling attendance in rural India, Jacoby and Skoufias (1997) show that child labor varies with income shocks, suggesting that child labor does cope against adverse economic shocks. In Tanzania, Beegle et al. (2006) find that transitory income shocks lead to increases in child labor, particularly in households who have no asset. The effect also appears in developed economies, mostly in cases where access to social security is limited (Cullen and Gruber, 2000; Hardoy and Schoene, 2013), as well as where the tax system is not too discouraging for the participation of married women activity (Harkness and Evans, 2011). Using PSID data from 1968 to 1992, Stephens (2002) revisits the AWE in the US and shows that the number of working hours of married women increases by as much as 11 percent in the four years following their husband's displacement. In Japan, over the period 1993-2004, the AWE accounts for 2.1 to 2.7 percent of the increase in married women labor market participation (Kohara, 2010). Between 2001 and 2007, Australian women with husband experiencing a job loss are 2.8 percentage points more likely to be employed full time than similar women with employed husband (Gong, 2011). During the 2007-2009 recession in the US, a married woman with displaced husband is 4 percentage points more likely to participate in the labor market than her counterpart married to an employed husband (Starr, 2013).

In Argentina, the AWE hypothesis is generally acknowledged as a main explanatory factor explaining the increase in labor market participation of married women after 1990 (Ministerio del Trabajo, 2005). Between 1970 and 1990, following the same trend as other countries in the Cono Sur (Argentine, Brazil, Chile, Uruguay), female participation rate rose from 31.4 to 50.2 percent of the female working age population. However, before 1985, this trend was mainly driven by traditional factors, namely changes in fertility and education, combined with a structural change in economic activities towards services. In the aftermath of the 1989 hyperinflation, a series of liberal measures were undertaken, implying waves of privatization and labor market flexibility measures, which created the conditions for economic growth, at the cost of a burst in unemployment. The increase in unemployment coexisted with an increase in married women participation, giving credit to the AWE hypothesis. Building on this stylized fact, Cerrutti (2000) explores the relationship between the increasing employment instability of male heads of household and the increasing female labor force participation using panel data. She finds that between 1991 and 1994, in the Great Buenos Aires area, a married woman whose husband experiences instability in his employment status is twice as likely to enter the labor market than a woman whose husband remains employed over time.

However, this positive correlation between a growing husband unemployment rate 
and female labor market participation faded out in the second half of the decade. In 2001, male unemployment rate kept up with its historically high 1995 level, whereas female participation slightly decreased. Did the AWE disappear completely? Could it be that the 1991-1994 AWE exhausted the stock of married women with the lowest reservation wages? Or did the discouraged worker effect prevail over the AWE at the aggregate level? ${ }^{3}$

Using the Encuesta permanente de hogares (EPH) panel data between 2000 and 2002, this paper aims at assessing the existence and magnitude of the AWE during the 2001 economic crisis in Argentina. Identifying the causal effect of a household head unemployment or income loss on his spouse's labor market outcomes is challenging because spouses simultaneously allocate their time between leisure, home and market production according to a utility function including both spouses' preferences. Female labor supply is the result of a household maximisation process that evolves taking into account changes in market wages and tastes, or alternatively the result of a bargaining process in case of a collective intra-household labor supply model. ${ }^{4}$ Without a proper identification strategy, the AWE would spuriously account for these decisions that are not coping strategies against unexpected shocks.

In this paper, we take advantage of the 2001-2002 sudden crisis episode in Argentina. During the 1990s, Argentina was indeed presented as the IMF's model pupil. Under President Carlos Menem and Minister of Finance Domingo Cavallo, a set of neoliberal measures were undertaken from 1991 onwards to restore trust into the domestic currency, to foster foreign investments flows and to fight against hyperinflation. In April 1991, the Convertibility plan established a currency board that irremediably pegged the Argentine peso to the US dollar. The main achievement of this currency board has been to durably contain inflation - the pest of Argentine economy for decades, and restore trust into the domestic currency. The 1990s were a period of sustained economic growth, and Cavallo consequently gained a huge popularity among the middle class. ${ }^{5}$ However, from 1999

\footnotetext{
${ }^{3}$ In their study of the AWE in Spain between 1968-2007, Congregado et al. (2011) find that the AWE dominates the discouraged worker effect, but only when unemployment is below a 11 percent threshold. Above this threshold, the two effects cancel each other out: married women participation rate is not influenced by further deterioration of economic conditions. If this is the case, the AWE disappears at the aggregate data level, but should still be observed at the individual data level.

${ }^{4}$ For example, if the leisure of both spouses are substitutes, the correlation between the labor supply decisions of both spouses within the household simply picks up the intra-household decision process where husbands and wives commonly decide of a new allocation set between labor and leisure, keeping the overall household welfare constant.

${ }^{5}$ An exception is the 1995 recession. It corresponds to the Mexican 'Tequila' crisis affecting the whole region.
} 
onward, a combination of external and internal factors made it increasingly difficult for an Argentina in moderate recession to sustain the Convertibility regime (Fanelli, 2002). Nonetheless, throughout the difficulties, Argentina was repeatedly backed by the IMF. The situation suddenly escalated from November 2001 onwards. The highly unpopular corralito measure - consisting in freezing banking accounts to limit possibilities of a bank run - and the sudden stop to the Argentine financial support decided by the IMF a few days later triggered the social, political and economic collapse of December 2001. The sudden end of the Convertibility era in January 2002 creates an unanticipated shock, asymmetrically affecting the different economic sectors. This exogenous, asymmetric variation is exploited as an instrument for the observed variations in labor earnings and employment status of the household head. The EPH database provides information on households directly before and after the sudden collapse of the Convertibility. By selecting the variations in income and unemployment that are unrelated to the classical intrahousehold bargaining process, the IV estimation allows for a causal identification: under the common trend and exclusion restriction assumptions, this estimation strategy yields an unbiased estimate of the AWE in Argentina.

This paper's contribution to the literature is threefold. A first distinguishing feature of this paper is its innovative identification strategy. The fact that panel data are an absolute requirement for studying household-level labor supply responses to shocks is well-known, and has been repeatedly assessed in the literature (MaCurdy, 1985, Blundell and Macurdy, 1999; Stephens, 2002). Nonetheless, studying the effects of an economic shock in emerging countries rarely involves panel data analyses. A notable exception to this criticism is Cerrutti (2000)'s paper on the AWE in the Great Buenos Aires area. However, in our view, even when using panel data, the estimated positive correlation between the household head's employment stability and the married woman's entry on the labor market captures other effects unrelated to the AWE. First, such a correlation appears whenever spouses' leisure times are substitutes, which would be unrelated to shock coping. Second, Cerrutti (2000)'s variable of interest is a dummy standing for changes in the occupation status of the household head (job loss and job entry), not just job loss. This is problematic, because it makes it impossible to see whether the positive correlation means that female labor supply acts as a counter or rather procyclical force with respect to the decline in family earnings due to the primary earner income loss. Our paper adds an IV strategy to the use of panel data in order to identify the AWE. Natural experiment settings using economic shocks to reveal strategical responses from households are still sparse, though promising methods (Yang, 2008). To our knowledge, this paper is among the very few relying on an IV strategy to causally estimate the AWE. ${ }^{6}$

\footnotetext{
${ }^{6}$ Interestingly, parallel to our paper, a recent study by Ayhan (2014) investigates the AWE in Turkey.
} 
Second, this paper adds to the existing literature on female labor supply and intrahousehold decision process by collecting information on labor supply decisions in an emerging economy. So far, the AWE was predominantly computed for industrialized countries, leaving aside the developing world, where the family is assumed to play an important shock coping role in the absence of a universal social safety net. Understanding the process by which household labor allocation occurs is important for policy and project design (Haddad et al., 1997), as indirect implications of this increase in participation are unclear for own and other household members' welfare (Lim, 2000; Klasen and Pieters, 2012).

Finally, this paper contributes to the literature on AWE by stating the clear distinction between its aggregate and micro dimensions. It untangles the fact that the AWE at the micro level is a necessary condition for the macroeconomic AWE to exist, but that the reverse does not necessarily hold. The concept of AWE confusingly builds on two very different strands of literature that should not be assimilated. We show that the AWE should not be discarded as a candidate to understand the labor supply decisions of Argentine women, even if the negative correlation between labor outcomes of married spouses washes out at the aggregate level.

Our findings suggest that in the absence of a sufficient safety net, shock coping is still one of the functions of marriage. A simple regression analysis using individual fixed effects reveals that the average 32 percent decrease in husband real monthly labor income is associated with a 0.55 percentage point increase in married women participation, which represents half of the variation observed over the period at the aggregate level. A woman whose husband looses his job is 7.3 percentage points more likely to enter the labor market, 4 percentage points more likely to find an occupation, and almost 2 percentage points more likely to work full-time. When instrumenting for husband labor market outcomes, we find that the causal effect of a negative shock affecting the household is even higher. On average, married women are 4.4 percentage points more likely to supply labor at the extensive margin. If we adopt stricter definitions of participation, the effect still accounts for a 2.1 percentage points increase in married women participation over the period. In spite of the constraint on the demand side of the labor market, married women whose husband experiences the average decline in labor earnings still have a 1 percentage point higher probability to find a full time job. When a household head experiences an unexpected displacement, his spouse is 43 percentage points more likely to enter the labor market, and 35 percentage points more likely to be employed. At the intensive It exploits the 2008 economic crisis, and instruments the displacement of the household head with the variation in the production level of the male-dominated sectors induced by the crisis. 
margin, the results are in line with expectations, but the pattern is less clear-cut. On average, following the job loss of their husband, four out of ten employed women express the willingness to work more hours. However, they face a constrained demand and this willingness to work does not effectively translate into more hours. In addition, interesting wealth and income effects arise when studying heterogeneities in the AWE.

Section 1 briefly recalls the theoretical background under the concept and the mechanism of the 'added worker'. Section 2 details the empirical strategy, gives key elements of the Argentine political and economic context, and outlines the construction of the instrument sets. Section 3 presents the dataset. Section 4 displays and comments the main results. Section 5 conducts a sensitivity analysis and various robustness checks. Section 6 gives insights on heterogeneous effects within the AWE. Last section sums up the results and concludes.

\section{Transitory income shocks and changes in house- hold labor supply: theoretical considerations}

Female labor supply has been increasing steadily during the last century. From this standpoint, three topics are particularly relevant (Mincer, 1962; Killingsworth and Heckman, 1986): the role of the family, the allocation of time between market, non market activities, and leisure, and the heterogeneity of human capital and available jobs. The study of the AWE clearly relates to the role of the family. Does the marriage work as a compensation mechanism against adverse economic shocks? What is the motivation for shifts in labor supply: leisure complementarities, variations in the relative labor market opportunities of household members, an income diversification in situation of perceived higher risk, or a strategic response to shocks? Does the labor supply of other family members allow to compensate an income loss? So far, the existing empirical studies have built on a variety of theoretical settings to try to pin down the AWE. In what follows, we briefly sketch the theoretical labor supply model behind our empirical analysis.

In the static model (Killingsworth and Heckman, 1986), a negative shock on the income of the household head reduces the relative value of his spouse non-market time, and as such foster a reallocation of the labor supply within the couple toward the spouse. However, the opportunity cost of leisure decreases with economic opportunities. If the shock affecting the income of the household head is aggregate, then the added worker effect may well be mitigated by an income effect, or the so called discouragement effect. Since the additional labor supply provided by the spouse is one out of many options for 
a household to adjust for a loss in income, its importance is linked with the availability of alternative coping strategies: a more intensive job search by the husband or other household members, access to credit or financial support from the community, capital destruction, and so on.

In a life-cycle model, the added worker effect does not show up. Indeed, the transitory component of the income does not come into play, and the labor supply only responds to declines in permanent income (MaCurdy, 1981). Nonetheless, if uncertainty is postulated and introduced into the model, the labor supply can vary even in the presence of temporary shocks, because the shocks now convey information on the earning prospects and as such have an impact the marginal effect of wealth across periods (MaCurdy, 1985).

Accordingly, the theoretical background of this paper is a unitary household life cycle model of labor supply under uncertainty, extended to the household case by Stephens (2002). In short, life-cycle modeling under uncertainty extends the standard static, deterministic models introducing life-time and randomness through the marginal utility of wealth. The static budget constraint is replaced by an asset accumulation path constraint. The Lagrange multiplier no longer represents the marginal utility of income but the marginal utility of wealth. Finally, uncertainty is introduced into the model by allowing the marginal utility of wealth to follow a stochastic process over the lifetime.

Assume a household composed of two working age individuals. The household utility is quasi-concave, and depends on consumption $C$, working hours of its two members $H^{j}$, $j=h, w$ and shifts in preferences $Z$. Typically, taste shifters for labor-leisure trade-off include children as observed variables, or health status and taste for work as unobserved variables: $Z_{i t}=X_{i t}+v_{i t}$. The price of consumption good is normalized to 1 . The household utility in a life-cycle setting depends of present and future values of $C, H^{j}$ and $Z$. For tractability, utility separability in time is assumed. At age $t$, the household optimization program is:

$$
\max U_{t}=E_{t}\left[\sum_{s=t}^{T} \delta^{s-t} U_{s}\left(C_{s}, H_{s}^{h}, H_{s}^{w}, Z_{s}\right)\right]
$$

For simplicity, the model realistically assumes $\mathrm{T}$ to be known by agents. The maximization of utility is subject to a budget constraint described by the time path of asset accumulation and a terminal condition:

$$
\begin{aligned}
A_{t+1} & =\left(1+r_{t+1}\right)\left(A_{t}+B_{t}+W_{t}^{h} H_{t}^{h}+W_{t}^{w} H_{t}^{w}-C_{t}\right) \\
A_{T} & \geq 0
\end{aligned}
$$


with $A_{t}$ the real value of assets in $t, B_{t}$ the non-labor, non-asset income, $W_{t}^{j}$ the hourly wage rate for household member $j=h, w$, and $Y_{t}$ the household non-labor income.

Under dynamic programming, expression (1) is reformulated as the consumer's value function.

$$
V\left(A_{t}, t\right)=\max U\left[\left(C_{t}, H_{1 t}, H_{2 t}, Z_{t}+\delta E_{t}\left[V\left(A_{t+1}, t+1\right)\right]\right]\right.
$$

At age t, consumers choose their values of $C$ and $H_{i}$ subject to (2a). First order conditions yield:

$$
\begin{aligned}
\frac{\partial U}{\partial C}\left(C_{t}, H_{t}^{h}, H_{t}^{w}, Z_{t}\right) & =\lambda_{t} \\
-\frac{\partial U}{\partial H_{t}^{h}}\left(C_{t}, H_{t}^{h}, H_{t}^{w}, Z_{t}\right) & \geq \lambda_{t} W_{t}^{h} \\
-\frac{\partial U}{\partial H_{t}^{w}}\left(C_{t}, H_{t}^{h}, H_{t}^{w}, Z_{t}\right) & \geq \lambda_{t} W_{t}^{w} \\
\lambda_{t} & =\delta E_{t}\left[\left(1+r_{t+1}\right) \lambda_{t+1}\right]
\end{aligned}
$$

The first three conditions are similar to the static labor supply case, with the important distinction that $\lambda_{t}$ now describes the marginal utility of wealth at age $t$, and not the marginal utility of labor income. At age $t$, the household chooses its consumption level so that the last unit consumed costs as much as giving up a unit of savings (equation (4a)). Conditions (4b) and 4c reveal which quantity of labor will maximize household utility, preference for leisure being allowed to vary among family members. If the inequality holds strictly for member $j$, all of his time $\bar{L}$ is allocated to leisure, and $j$ supplies no hours of work. Finally, the Euler equation in (4d) describes the allocation rule for wealth across the life-cycle under uncertainty. Households determine their labor supply, consumption and savings in order to equalize the marginal utility of wealth $\lambda_{t}$ in current period $t$ with the expected discounted value of marginal utility of wealth in $t+1$.

When a household head experiences a negative shock on his earnings $W_{t}^{h}$, his spouse's labor supply first reacts through a cross wage effect implied by $4 \mathrm{~b}$ ) and (4c): holding $\lambda_{t}$ constant, the wife responds to a change in $W_{t}^{h}$. The sign of this adjustment is ambiguous, because it depends on leisure complementarities between spouses.

In addition, under uncertainty, the labor supply of the wife responds to another argument: $\lambda_{t}$, according to a wealth effect described in $4 \mathrm{~d}$ ). Recall that under perfect certainty, $\lambda_{t}$ simply summarizes all information about lifetime wages and property income outside the decision period that a consumer needs in order to determine his optimal 
current consumption and labor supply (MaCurdy, 1981). By definition, no wealth effect on the labor supply of married women is to be observed, since the life cycle wage profile is known by households. Under uncertainty, unanticipated shocks are introduced through the marginal utility of wealth, which now follows a stochastic process. Variations in $\lambda_{t}$ conveys information on these unanticipated shocks to the household's optimization decision process through the saving allocation rule given by equation (4d). According to $4 \mathrm{~d}$, expectations of the future value of the marginal utility of wealth is equal to the present observed value: households revise their expectations for the next period by taking into account their forecasting errors realized at $t$. These forecast errors are assimilated to unanticipated shocks, having impacts on future expected wages, non-labor income, taste shifter variables (Dynarski and Sheffrin, 1987). For example, an unexpected decrease in wages between $t-1$ and $t$ leads the household to compute his actualized $\lambda_{t}$ from anticipated value $E_{t-1}\left[\lambda_{t}\right]$ and realized forecast error $\epsilon_{t}^{*}$. Assuming concave preferences, a decline in wealth generates a revision of the marginal utility upwards for future period $t+$ 1. In return, this impacts positively the labor supply of married women. The magnitude of the positive effect depends on the expected consequences in terms of future income flows, and the probability that the household had anticipated this shock. The higher the expected consequences and the lower the perceived probability of the negative shock, the higher the resulting AWE.

We have described the mechanisms underlying the theoretical AWE. In what follows, we detail our empirical strategy, in accordance with the theoretical implications of the model.

\section{Estimation strategy}

In order to measure the causal effect of a household head's evolution in labor market outcomes on his partner's labor supply, this paper relies on panel data and develops an instrumental variable strategy.

There are at least three reasons why panel data is preferable to a repeated cross section for the sake of our analysis. First, empirical models based on the standard Mincer equation have no behavioral interpretation in a life-cycle framework. Indeed, when regressing hours worked on the hourly wage, the estimated coefficient captures the response of labor supply to wage changes along three directions: wage changes arising from movements along a wage profile, shifts in a wage profile, and changes in the profile of the slope (MaCurdy, 1981). From the theoretical discussion in Section 1, it should be clear that the use of panel data is an absolute requirement to capture the AWE. Indeed, since 
the marginal utility of wealth $\lambda_{t}-$ a key theoretical component - is household-specific and unobserved, it should be taken into account and differentiated out (Blundell and Macurdy, 1999). In addition, with labor market conditions deteriorating over the period, probabilities of being employed are likely to fall for spouses with non-employed partners as well, even if they produce an extra effort to find or keep a job. Finally, the pool of households with unemployed heads is likely to differ strongly according to whether the economy is booming or in the midst of a deep recession. A repeated cross section would compare households that differ with respect to unobserved characteristics, and this unobserved heterogeneity would partly contribute to the measured difference in difference between a spouse with a non-employed partner and an observationally identical spouse with an employed partner (Starr, 2013).

From the discussion above, unlike estimations relying on cross-sectional data, fixed effect estimations allow to measure the correlation in labor supply decisions within the household, abstracting from spurious correlations due to unobserved differences between households. This being said, in our case, the estimated correlation is not necessarily causal. The negative correlation between job loss of husbands and their spouse's activity is certainly at least partly driven by behavioral decisions. Such a negative correlation arises whenever the leisure time of spouses are substitute to one another, which would correspond to the cross wage effects described in Section 1. The job loss of the household head is not necessarily perceived as a negative income shock exogenously affecting his spouse's participation. Unemployment can be seasonal, or correspond to a quit. In this case, no shock coping mechanism is to be expected from the spouse, since unemployment is part of the household welfare optimization. In addition, since expectations and perceived probabilities are the key ingredients of the theoretical mechanism described in Section 1, our empirical strategy should allow to disentangle the ex ante insurance mechanism from the ex post coping strategy corresponding to the AWE.

For these reasons, our identification relies on an exogenous (unanticipated) source of variation in the labor market outcomes of the heads of household. In what follows, we present our IV strategy. ${ }^{7}$ In equation (5), $W_{i t}$ is our variable of interest and stands for

\footnotetext{
${ }^{7}$ Other strategies have been used to isolate the AWE related to unexpected shocks from behavioral motives. In particular, involuntary unemployment, and specifically plant closure events, has been used to circumvent the endogeneity issue (Stephens, 2002). Nonetheless, this estimation strategy necessarily restricts to the private sector, which reduces the external validity of the results with respect to the whole population. In addition, during the Argentine crisis, negative income shocks mainly happened through declines in nominal and real wages, and not uniquely through unemployment (McKenzie, 2004). Accounting for exogenous shocks in unemployment would tell only one half of the story, leaving aside decreases in wages.
} 
the labor market outcome of the head of household $i$. $Y_{i t}$ is the labor market decision of his spouse. $\mu_{i}$ is the unobserved fixed effect that may be correlated with levels of $W_{i t}, \phi_{t}$ is a time fixed effect, $\epsilon_{i t}$ represents a time varying idiosyncratic error. $X_{i t}$ is a matrix containing information on time-varying household characteristics and partners' characteristics.

$$
\begin{aligned}
& Y_{i t}=X_{i t} \beta+\hat{W}_{i t} \gamma+\mu_{i}+\phi_{t}+\epsilon_{i t} \\
& W_{i t}=X_{i t} \beta^{\prime}+Z_{i t} \alpha+\mu_{i}^{\prime}+\phi_{t}^{\prime}+\epsilon_{i t}^{\prime}
\end{aligned}
$$

Since $W_{i t}$ is endogenous, it is instrumented by $Z_{i t}$. The IV $Z_{i t}$ relies on a typical natural experiment framework and exploits variation in time and across economic sectors. According to their sector of occupation, the labor outcomes of the household heads are asymmetrically affected by the sudden, unexpected end of the Convertibility era in December 2001.

Figure 1 conveys the intuition behind the instrument $Z_{i t}$. It displays the growth rates at a sectoral level between 1991 and 2005.

FIGURE 1 - GDP yearly growth rate 1992-2005, by primary/goods and service sectors
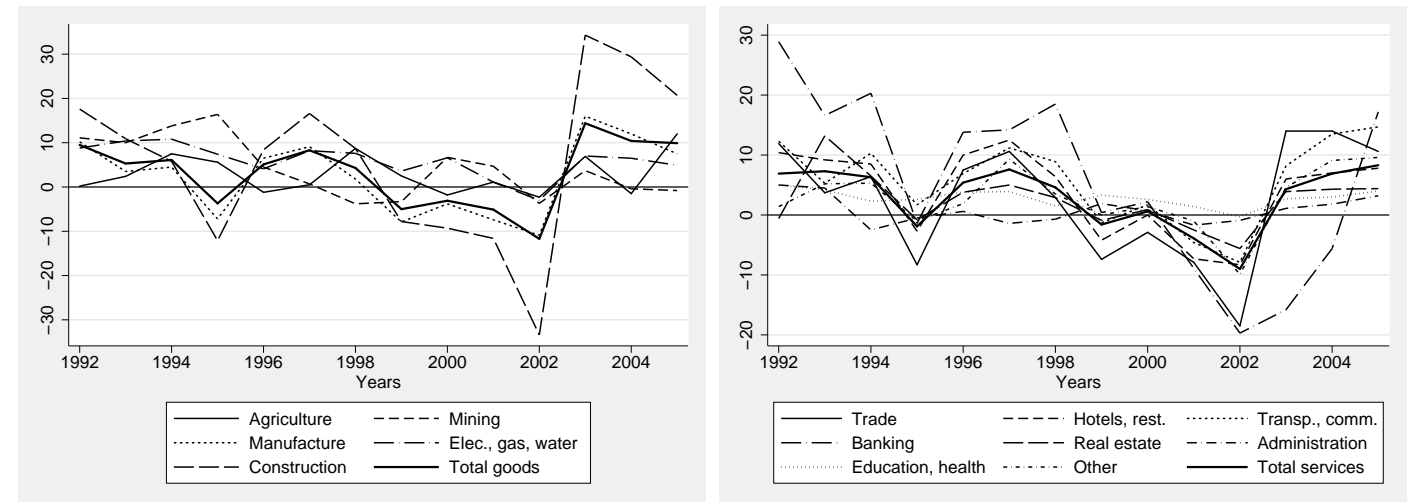

The 2002 deep recession clearly contrasts with the growth period of 1992-1998, and even with the mild recession happening in 1999-2000, usual in a volatile emerging economy. Indeed, during the post-Convertibility crisis, the sectoral asymmetry in growth rates is large, and exacerbated with respect to the growth and mild recession periods. Certainly, during the growth period before 1999, asymmetries are to be noted, however the volatility is general and rather erratic - especially before 1995. During the mild recession years (1999-2001), growth rates are still either around 0 for all tertiary sectors, or concentrated in a $-10 /+10$ bandwidth for secondary sectors. In contrast, after the outburst of the crisis in December 2001, the recession rates differ greatly between sectors: -30 percent for the construction sector, -20 percent for the banking sector against 0 percent growth for mining and -5 for the real estate sector in 2002 . 
For robustness purposes, we construct three different versions of the instrument. All the defined instruments exploit the variation in time as well as the asymmetry between exposed and preserved economic sectors, and control whether the household head changed sector within the observation window. Each set of instruments thus contains three variables: a dummy variable equal to 1 if the observation was collected after December 2001, a variable measuring the sector exposure, and an interaction term between these two variables. The sets of instruments differ with the measure of 'exposure'. In addition, whereas the first two instrument sets rely on EPH data, the last instrument is constructed using information on the log sectoral GDP provided by the Argentine statistical agency INDEC.

To define the first two instrument variables sets, we first regress the labor income of the household head $W_{i t}$ on a dummy variable $S_{i t}$ standing for the post Convertibility period. We use a panel estimator with individual fixed effects. Then, the same estimation is run separately for each of the 22 economic sectors $s$, as seen in equation (6).

$$
\begin{gathered}
W_{i t}=a_{0}+a_{1} S_{i t}+c_{i s}+u_{i t} \\
W_{i t s}=a_{0 s}+a_{1 s} S_{i t}+c_{i s}+u_{i t s}
\end{gathered}
$$

The coefficient $a_{1 s}$ is a measure of sectoral exposure. ${ }^{8}$ We define a sector $s$ as exposed if household heads employed in this sector experience a negative and significant degradation in $W_{i t}$ between 2001 and 2002 ( $a_{1 s}$ significant and negative), and if sector $s$ suffers relatively more than other sectors (i.e., $a_{1 s} \geq a_{1}$ ). For the first set of instruments (IV1), the asymmetric shock is the interaction between the exposure dummy and the post Convertibility time dummy. The second instrumental variable set (IV2) relies on the intensity of the economic shock. It relaxes the rigidity of this asymmetry, and uses directly $a_{1 s}$ instead of the $0 / 1$ dichotomy. In this case, the exposure dummy still defines whether the sector is a later to be exposed or protected one, and the interaction between $a_{1 s}$ and the post Convertibility time dummy stands for the negative asymmetric shock. Finally, a third instrument set (IV3) is generated using sectoral GDP data between 2000 and 2002. The information is less disaggregated, and relies on 13 sectors of activity instead of the 22 sectors of the EPH. The set IV3 thus contains: the log GDP of the 13 sectors, the post Convertibility dummy, and the interaction between the two. Estimates for specification (6) and IV definitions are presented in Appendix. The top panel of Table 14 gives results for primary and secondary sectors, and the top panel of Table 15 displays results for service sectors. Definitions of the sets $I V 1$ and $I V 2$ are reported in

\footnotetext{
${ }^{8}$ Alternatively, equation (6) can be estimated defining $W_{i t}$ as the household head's unemployment instead of his labor income. Results are very similar, thus not reported here.
} 
bottom panels of Tables 14 and 15. GDP data used for $I V 3$ are plotted in Figure 1.

The validity of the estimation design presented in (5) is conditioned on several assumptions: (i) As usual in an instrumental variable approach, the exclusion restriction must hold: the asymmetrical change in labor market outcomes of the household head has no direct influence on the labor supply decision of his spouse, except through the endogenous regressor instrumented: $\operatorname{cov}\left(Z_{i t}, \epsilon_{i t}=0\right)$. Additionally, the instrument should not be too weakly correlated with the endogenous regressors, because IV estimators perform poorly when instruments are weak (Stock and Yogo, 2002). (ii) As common in linear probability models with individual fixed-effects, the empirical strategy exposed above is valid if the common trend assumption holds. The shock should be exogenous: there should be no anticipation due to superior information, no biased attrition, nor group manipulation, i.e. individuals shifting sectors. In addition, there should be no time-varying unobserved variable that can affect both the interest and outcome variables. Under these assumptions, the IV procedure enables to capture the causal effect of $W_{i t}$ on $Y_{i t}$. Additionally, it corrects for the attenuation bias resulting from measuring error in the labor income of the household head $W_{i t}$.

To our view, the asymmetrical sectoral shock is a good instrument, primarily because it has no direct influence on the labor supply decision of his spouse, but is strongly correlated to the labor outcomes of the household head. Indeed, on the subsample of women participating on the labor market before 2001, the wife's sector correlates poorly with her husband's. We may think that women's skills are more prone to be valued in the relatively protected sectors. For this reason, we account for the evolution in labor market opportunities for female, to capture labor supply effects related with the evolution in the economic environment, but disconnected from personal household situations. We do so by computing a wave-region-age-education hourly wage relative to the wage rate faced by males with similar characteristics, and introducing it into $X_{i t}$ in (5). ${ }^{9}$

For the purpose of instrumentation, the fact that the end of the Convertibility was widely unexpected is an additional important feature of the negative shock conforting our identification strategy. Here, some elements of context are required to support the view that the shock was indeed unexpected by married women, i.e. exogenous to married women participation. As the best pupil of the Washington Consensus, Argentina was repeatedly backed by the IMF throughout the 1990s. The situation suddenly escalated after November 2001, when the IMF decided to cut its financial support, thus deceiving the optimistic anticipations based on the currency board. The deep degradation in Ar-

\footnotetext{
${ }^{9}$ The second panel of Table 2 (Section 3 ) suggest that if anything, labor market opportunities of women relatively to men are worsening during the period.
} 
gentine economic indicators took economists by surprise. In October and November 2001, most predictions were optimistically announcing a zero growth or a moderate recession McKenzie, 2004). ${ }^{10}$ In this context, the collapse of the currency board change regime is likely to have been largely unanticipated by Argentine households. Under this exogeneity assumption, the pre-crisis labour market participation decisions were not related to the imminence of a deep crisis. On the other hand, post-crisis adjustments in labor market participation can legitimately be interpreted as strategical responses to this new information.

From the discussion above, the orthogonality of the sector of spouses, as well as the sudden collapse of the currency board change regime, give credit to the exogeneity assumption. However, the other assumptions do not necessarily hold for a series of reasons. Possible threats to the validity of our estimation strategy are threefold: panel attrition, timing or group manipulation (i.e. individuals anticipating the events to come or shifting sectors strategically), and time varying confounders.

Specifically, one possible candidate for confoundedness is the poverty alleviation program Jefes y jefas de hogar (herafter JJH) extended in 2002, which could play the role of a time varying confounder and bias the estimation results. The JJH program was introduced in January 2001 as an extension to the Trabajar I (1993) and Trabajar II (1996) workfare programs. Eligible to the program are unemployed household heads with at least one child under 18. Though the program is universal, 20 weekly working hours are required as a counterpart for the $150 A R \$$, in order to target the poorest households, whose members have a lower reservation wage. Following the end of the Convertibility era, the program had been largely extended from April 2002 onwards. In theory, this program simply relaxes the constraint on labor demand by offering low paid activities under the market wage rate. In practice, the rapid extension of the program casts doubts on the enforcement or the work requirement. This workfare program is a potential source of estimate bias for two reasons. First, institutions had no possibility to know who was the head of the household, which drove women into soliciting this complementary income while husbands were searching for work - or were involved in informal activities (Galasso and Ravallion, 2004). This creates a spurious correlation between a husband unemployment and his spouse's participation decision. Second, the program allocation decision is highly decentralized and distributed according to a "first

\footnotetext{
${ }^{10}$ For example, in the December 2001 World Economic Outlook, the IMF predicted a 1.1 percent decline in GDP coupled with $0.5 \%$ deflation for 2002. These forecasts evolved rapidly in response to December 2001 events. McKenzie (2004) reports that the Economist Intelligence Unit Country Report issued in January 2002 drastically revised its GDP forecast from $-1 \%$ to $-7 \%$ and its inflation predictions from $-0.6 \%$ to a $12.7 \%$ increase in consumer price index.
} 
come, first served' basis with high level of clientelism through syndicates and piqueteros associations (associations of unemployed individuals protesting and blocking roads to defend their right to jobs and social protection). Indeed, observers in randomly picked localities reported a strong heterogeneity in levels of control for compliance with working hours counterpart. This windfall effect is likely to bias the measured added worker effect upwards, because the women benefiting from moral hazard or local acquaintances would otherwise not have been seeking a job.

Besides the intuitions exposed here, Section 5 formally tests the robustness of the results. We first check the sensitivity of the results to the workfare program JJH: possible windfall effects of the program are accounted for using a restrictive, conservative definition of female participation. We then test the common trend hypothesis with the help of a Placebo test arbitrarily defining the outburst of the crisis in October 2001. The attrition bias is tested with a series of mean tests across survey waves. Finally, we check to what extent the results are robust to the existence of superior information - households anticipating the negative shock - or group manipulation - individuals shifting sectors strategically between October 2001 and May 2002.

\section{Data}

The data for this study comes from the Encuesta Permanente de Hogares, hereafter EPH. The EPH is collected by Argentina's National Statistical Agency (Instituto Nacional de Estadisticas y Censos, herafter INDEC) in May and October of each year in 28 main urban areas. The survey is a rotating panel: each household is followed during at most 18 months (four waves), then rotated out. Each wave contains information on employment, as well as demographic, economic, and social characteristics of roughly 90000 individuals in 30000 households. Non-response represents roughly $20 \%$ of the available information. Like most extensive household surveys, the survey uses a geographical criteria, and follows household dwellings, rather than specific groups of individuals. Households moving to another area are not followed. To avoid mismatching, the spouse's age cannot differ by more than one year from one wave to the next (McKenzie, 2004).

To investigate how the labor market outcomes of spouses are affected by dynamics at work within the household, we extract information on couples with working age spouses (women aged 16-60 and males aged 18-65) from the May 2000 wave to the October 2002 wave. ${ }^{11}$ Married women receiving pension and perceiving unemployment benefits

\footnotetext{
${ }^{11}$ The legal age for marriage is 16 for women and 18 for men. In 2001, children can theoretically work from the age of 14 ; however, children aged 14 to 16 are allowed to work up to 3 hours daily and 15
} 
represent respectively $2.54 \%$ and $0.15 \%$ of the whole sample of married women of working age. Because their participation decision is endogenous to these income sources, and in so far they represent an extremely small group, corresponding observations are dropped. Households whose head is retired or student are also excluded from the sample. Finally, the panel is restricted to households that are observed at least once before and after the end of the convertibility period. The final sample contains 15577 observations on working age couples with an active head between May 2000 and October 2002. ${ }^{12}$

In the data, the negative income shock experienced by household heads is defined as a decline in real monthly labor income, or alternatively as a job loss. Married women can respond to this negative shock experienced by their husband by supplying work at the extensive margin or at the intensive margin. As for the extensive margin, participation is a dummy variable equal to 1 if the spouse is currently employed or declare to be actively looking for an occupation. Occupation is a dummy standing for employment only, unemployed labor market participants being redefined as 0. A dummy for full time employment signals whether the spouse is currently employed and works at least 21 weekly hours. This leads almost half of the program beneficiaries to be redefined as inactive. These measures of labor supply are completed by taking into account the workfare program Jefes y jefas de hogar. As explained in Section 2, the implementation of the program may have created windfall effects, biasing the results upwards. To account for this possibility, we generate a stricter version of the participation and occupation dummies, where beneficiaries of the workfare program are assigned a 0 instead of a 1 , unless they work strictly more than the minimum legal amount of hours, or declare working the legal number of hours and wishing to work more hours. ${ }^{13}$ Finally, at the intensive margin, this paper concentrates on two labor supply measures: actual weekly working hours, and a dummy variable equal to 1 if the spouse expresses the willingness to work more hours. The sample is restricted to married women who declare working a strictly positive amount of hours during the period. ${ }^{14}$

All specifications in this paper are estimated using a panel data model with individ-

hours a week during the morning or afternoon, as long as the work is within a family business, is not hazardous, and does not interrupt schooling. Between 1994-2002, an ongoing pension reform gradually changed the pension age for men and women. The retirement age is 62 for men and 57 for women in $1994,63 / 58$ in $1996,64 / 59$ in 1998, and 65/60 since 2001. In this study, the working age for women is defined following the 2001 legislation.

${ }^{12}$ The main analysis is based on this sample. The robustness checks typically use a larger sample going back to the May 1998 wave.

${ }^{13}$ Additional robustness checks are conducted in Section 5

${ }^{14}$ We do not model the sample selection, in so far it requires a convincing exclusion restriction. Results have to be interpreted accordingly. 
ual fixed effects. Serial correlation is accounted for by clustering the standard errors at the household level. All individual fixed effects are thus differentiated out in the within estimation procedure. However, time varying variables have to be accounted for in case they influence married women participation into the workforce.

Having additional children is a first time varying variable potentially influencing married women participation decisions. For this reason, we control for the variation in the number of pre-schooling children, children in compulsory schooling age, and children in working age. Another important time-varying variable is the availability of alternative shock coping strategies. There is no reason why households should pick up one strategy over the available set. As detailed by Frankenberg et al. (2003) in the 1997 Indonesian crisis case, households usually diversify their coping strategies to mitigate the negative effects of a shock on their well being. For this reason, and within the limits of available data, we control for alternative coping strategies using information on sources of nonlabor income: labor income coming from other household members, and a series of non labor income sources proxying for adjustment strategies (fluctuation in capital income) or network strategies (fluctuation in remittances from non-members).

Another reason for married women participation to rise could be that their opportunities on the labor market increase in absolute terms, or relatively to their male counterpart. This could be the case if the sectoral composition changes towards services. To control for this eventuality, we compute the mean unemployment rate and hourly wage rate faced by female workers at each wave-region-age-education level ${ }^{15}$, and include them into the regression. Furthermore, we include the ratio of hourly female wage rate on hourly male wage rate, calculated at the wave-region-age-education level as well, to account for an evolution in relative hourly wages.

Tables 1 and 2 present summary statistics on means for outcome, interest, control and demographic variables. ${ }^{16}$ Table 1 gives information on married women labor market decision and husbands' outcomes. As mentioned above, simple descriptive statistics are not supportive of an added worker effect. Women participation increased from 48.47 to 49.42 percent between 2000 and 2002, however, this difference is not statistically significant. In case JJH beneficiaries who do not declare working 20 hours weekly nor actively seeking to work more hours are redefined as inactive, the participation even tends to decline. The same evolution is observed at the intensive margin: conditional on being occupied during the convertibility period, married women work on average 5 hours less in

\footnotetext{
${ }^{15}$ There are 6 regions, 3 age categories (16-29, 30-44, 45-59) and 3 educational levels (primary or less, secondary, superior education)

${ }^{16}$ Means of time constant variables are actually not constant between 2000-2001 and 2002 because households can be observed twice before or after the currency board collapsed.
} 
TABLE 1 - Summary statistics: labor market outcomes of both spouses

\begin{tabular}{|c|c|c|c|}
\hline & \multicolumn{3}{|c|}{ Mean before and after Convertibility } \\
\hline & Before & After & Mean test \\
\hline \multicolumn{4}{|c|}{ Labor market outcomes, female } \\
\hline Participation $^{a}(\%)$ & 48.47 & 49.42 & 0.197 \\
\hline Participation $^{b}(\%)$ & 47.94 & 46.89 & 0.151 \\
\hline Unemployed (\%) & 5.06 & 5.87 & $0.016^{* *}$ \\
\hline Occupation (\%) & 43.41 & 43.55 & 0.845 \\
\hline Full time ${ }^{c}(\%)$ & 31.20 & 29.52 & $0.013^{* *}$ \\
\hline Self-employed (\%) & 7.93 & 7.10 & $0.032^{* *}$ \\
\hline Workfare program JJH (\%) & 1.70 & 4.62 & $0.000 * * *$ \\
\hline Hours worked & 29.44 & 25.62 & $0.000^{* * *}$ \\
\hline Add. hours supplied ${ }^{d}(\%)$ & 33.18 & 27.81 & $0.000^{* * *}$ \\
\hline \multicolumn{4}{|l|}{ Labor market outcomes, male } \\
\hline Participation $^{b}(\%)$ & 99.81 & 99.26 & $0.000^{* * *}$ \\
\hline Unemployed & 10.04 & 14.37 & $0.000^{* * *}$ \\
\hline Occupation & 89.96 & 85.63 & $0.000^{* * *}$ \\
\hline Full time ${ }^{c}(\%)$ & 81.80 & 75.57 & $0.000^{* * *}$ \\
\hline Self-employed (\%) & 8.77 & 7.84 & $0.022^{* *}$ \\
\hline Workfare program JJH (\%) & 1.43 & 2.56 & $0.000^{* * *}$ \\
\hline Hours worked & 41.68 & 37.30 & $0.000^{* * *}$ \\
\hline Add. hours supplied ${ }^{d}(\%)$ & 37.77 & 36.44 & 0.196 \\
\hline
\end{tabular}

Notes: Statistics on the 2000-2002 EPH sample of working age couples with active household head and being observed at least once before and after the currency board breakdown. P-values of differences, ${ }^{*} \mathrm{p}<0.1$, ** $\mathrm{p}<0.05$, *** $\mathrm{p}<0.01$. ${ }^{a}$ Participation is 1 if individual is employed or declare actively looking for a job. ${ }^{b}$ Participation rate excluding workfare program beneficiaries who do not declare looking for more hours or an other occupation. ${ }^{c}$ Full employment is working strictly more than 20 hours. ${ }^{d}$ Additional hours supplied is 1 if individual is employed and declares willing to work more hours. 
TABLE 2 - Summary statistics: income and household characteristics

\begin{tabular}{|c|c|c|c|}
\hline & \multicolumn{3}{|c|}{ Mean before and after Convertibility } \\
\hline & Before & After & Mean test \\
\hline \multicolumn{4}{|l|}{ Income } \\
\hline Husband monthly wage & 642.70 & 437.80 & $0.000^{* * *}$ \\
\hline Wife monthly wage & 219.74 & 154.99 & $0.000^{* * *}$ \\
\hline Monthly wage, other & 76.76 & 51.49 & $0.000^{* * *}$ \\
\hline Pension & 9.17 & 7.62 & $0.078^{*}$ \\
\hline Capital & 5.34 & 2.56 & $0.003^{* * *}$ \\
\hline Unemployment benefits & 3.99 & 3.69 & 0.742 \\
\hline Remittances & 3.11 & 2.16 & $0.014^{* *}$ \\
\hline Other & 12.85 & 8.10 & $0.040^{* *}$ \\
\hline Non-labor income & 34.45 & 24.13 & $0.000^{* * *}$ \\
\hline \multicolumn{4}{|c|}{ Macroeconomic opportunities, female } \\
\hline Mean unemployment & 15.52 & 16.39 & $0.000^{* * *}$ \\
\hline Mean hourly wage & 3.20 & 2.35 & $0.000^{* * *}$ \\
\hline Relative hourly wage & 0.64 & 0.63 & $0.000^{* * *}$ \\
\hline \multicolumn{4}{|l|}{ Demographics, female } \\
\hline Age (in years) & 38.13 & 38.93 & $0.000^{* * *}$ \\
\hline Primary or less (\%) & 38.63 & 39.45 & 0.255 \\
\hline Secondary (\%) & 39.18 & 39.07 & 0.876 \\
\hline Superior (\%) & 22.19 & 21.49 & 0.246 \\
\hline \multicolumn{4}{|l|}{ Demographics, male } \\
\hline Age & 40.89 & 41.70 & $0.000^{* * *}$ \\
\hline Primary or less (\%) & 41.23 & 41.89 & 0.357 \\
\hline Secondary (\%) & 40.32 & 40.16 & 0.817 \\
\hline Superior (\%) & 18.45 & 17.95 & 0.378 \\
\hline \multicolumn{4}{|l|}{ Demographics, household } \\
\hline Gran Buenos Aires & 15.47 & 12.70 & $0.000^{* * *}$ \\
\hline North-West & 20.33 & 20.62 & 0.632 \\
\hline North-East & 12.01 & 12.65 & 0.185 \\
\hline Cuyo & 11.31 & 12.07 & 0.106 \\
\hline Pampa & 26.47 & 26.88 & 0.532 \\
\hline Patagonia & 14.40 & 15.09 & 0.187 \\
\hline \multicolumn{4}{|l|}{ Household members } \\
\hline $\mathrm{Nb}$ child $0-5$ & 0.66 & 0.64 & $0.068^{*}$ \\
\hline Nb child 6-13 & 0.95 & 0.96 & 0.438 \\
\hline $\mathrm{Nb}$ child $14-17$ & 0.39 & 0.41 & $0.046^{* *}$ \\
\hline $\mathrm{Nb}$ older dependent & 0.05 & 0.05 & 0.669 \\
\hline
\end{tabular}

Notes: See Table1 All information on income is expressed in May 1998 pesos. 
2002 than in 2000-2001. Additionally, they do not show signs of willingness to work extra hours: on the opposite, the proportion of women willing to work more hours actually decreases significantly. This was to be expected because unemployment is rising between the pre and the post convertibility periods: labor supply mechanically decreases at the intensive margin, as part of the formerly employed married women now supply labor at the extensive margin again. As expected, the number of workfare program beneficiaries increases together with its extension decided in April 2002, and concerns $4 \%$ of married women in 2002 .

Table 2 conveys information on other time-varying variables detailed above. Unsurprisingly, all types of non labor income decreased, except unemployment benefits. ${ }^{17}$ Part of this decline is related to the 30 percent inflation following the peso devaluation; the rest is either nominal decrease, or asset selling in the case of capital income.

\section{Estimation results}

\subsection{Baseline estimation: fixed effect results}

As a preliminary analysis, we generate baseline estimates from a simple linear probability model with fixed-effects, in line with most of the existing empirical studies:

$$
Y_{i t}=X_{i t} \beta+W_{i t} \gamma+\mu_{i}+\phi_{t}+\epsilon_{i t}
$$

where $W_{i t}$ stands for the labor market outcomes of the household head at time $t$ (alternatively the labor earnings of the employment status), $Y_{i t}$ represents the labor supplied by his spouse, $\mu_{i}$ is the unobserved fixed effect that may be correlated with levels of $W_{i t}, \phi_{t}$ is a time fixed effect, $\epsilon_{i t}$ represents a time varying idiosyncratic error, and $X_{i t}$ is a matrix containing time-varying household characteristics and partners' characteristics.

Results of specification (7) are displayed in Table 3. A 30 percent decrease in the labor income of the household head (which is the mean evolution in household head labor income over the period) is associated with a 0.51 percentage point increase in his spouse's probability to enter the labor market (column 1). ${ }^{18}$ Going back to Table 1 , this represents half of the variation in female labor supply over the period. Turning to unemployment, it

\footnotetext{
${ }^{17}$ As mentioned above, households with wife cashing in unemployment benefits are dropped out of the sample for endogeneity issues. Unemployment benefits still concern 1.11 percent of the sample. In 86.6 percent of the cases, unemployment benefits belong to the household head.

${ }^{18}$ The fact that this effect could be driven by women withdrawing from the labor market when their husband reenters employment or get a better paycheck is a legitimate concern. To rule out this possibility,
} 
appears that a married woman is 7.3 percentage points more likely to enter the workforce if her husband looses his job. Since the unemployment probability for married men rises by 4.3 percentage points, this overall unemployment is related to a 0.3 percentage point increase in female participation. Accounting for potential windfall effects generated by the introduction of the workfare program does not dramatically change the results (column 2). As it was to be expected in such a depressed context, the added participants do not all find a job. Still, employment represents more than two third of the additional workforce (column 3) related to husband's losses in labor income or employment, half of which translating into full-time employment (column 5).

Finally, conditional on being employed, married women do wish to work more hours in case their husband experiences a negative shock on the labor market. The overall decline in income is related to a 0.3 percentage points increase in their probability to declare wanting additional working hours (column 6). However, at the intensive margin, this extra labor supply does not translate into more actual working hours (column 7). ${ }^{19}$

\subsection{IV estimation results}

we run the same estimations on the subsample of wives entering the labor force after the end of the Convertibility. As expected, using specification (7), the negative effect of the household head income on participation holds. This means that the effect is not driven by women withdrawing from the labor force. The size of the IV estimates more than doubles, and the precision increases.

${ }^{19}$ For the sake of completeness, we run a symmetric regression analysis with husbands' labor market outcomes as a dependent variable, explained by changes in their spouse's income or employment status. Since we concentrate on active women, the sample size shrinks down to half. Coefficients of interest are of expected sign, but of a much smaller magnitude, and not significantly different from 0. 
TABLE 3 - Female labor market participation and their spouse labor market outcomes - Linear probability results

\begin{tabular}{|c|c|c|c|c|c|c|c|}
\hline & \multicolumn{5}{|c|}{ Extensive margin } & \multicolumn{2}{|c|}{ Intensive margin } \\
\hline & (1) & $(2)$ & (3) & $(4)$ & $(5)$ & (6) & $(7)$ \\
\hline & Part & Part $^{+}$ & Occup & Occup $^{+}$ & Full-time & Wish more hours & Hours worked \\
\hline \multirow[t]{2}{*}{$\begin{array}{l}\text { Household head } \\
\text { monthly wage }\end{array}$} & $-0.017^{* * *}$ & $-0.013^{* * *}$ & $-0.013^{* * *}$ & $-0.009^{* * *}$ & $-0.004^{*}$ & $-0.010^{* *}$ & -0.059 \\
\hline & $(0.002)$ & $(0.002)$ & $(0.002)$ & $(0.002)$ & $(0.002)$ & $(0.004)$ & $(0.097)$ \\
\hline \multirow{2}{*}{$\begin{array}{c}\text { Household head } \\
\text { unemployment }\end{array}$} & $0.073^{* * *}$ & $0.059^{* * *}$ & $0.053^{* * *}$ & $0.040^{* * *}$ & $0.017^{*}$ & $0.069^{* * *}$ & 0.421 \\
\hline & $(0.013)$ & $(0.013)$ & $(0.012)$ & $(0.012)$ & $(0.010)$ & $(0.024)$ & $(0.573)$ \\
\hline Observations & 18755 & 18755 & 18755 & 18755 & 18755 & 7944 & 7944 \\
\hline \multicolumn{8}{|c|}{$\begin{array}{l}\text { Notes: } * \mathrm{p}<0.1,{ }^{*} \mathrm{p}<0.05, * * * \mathrm{p}<0.01 \text {. Standard errors in parentheses, clustered at the individual level. } \\
+ \text { Restrictive definition of participation and occupation: excludes JJH workfare program participants, unless they de- } \\
\text { clare working strictly more than the legal amount, or } 20 \text { hours and wishing to work more hours. }\end{array}$} \\
\hline \multicolumn{8}{|c|}{$\begin{array}{l}\text { Estimates from linear-probability regressions with individual fixed effects. The following time-varying variables are } \\
\text { included into the estimation: macroeconomic opportunities for female suppliers (mean unemployment rate at year- } \\
\text { region-age level, log mean hourly wage rate at year-region-age level, relative hourly wage rate with respect to male } \\
\text { counterparts at year-region-age level), household composition (number of children under schooling age, number of } \\
\text { children at compulsory schooling age, number of children in working age and under 18, number of third generation } \\
\text { parents), alternative sources of income (other labor income, pension, capital income, unemployment indemnities, re- } \\
\text { mittances, other), and time fixed effects for each observation wave. }\end{array}$} \\
\hline
\end{tabular}




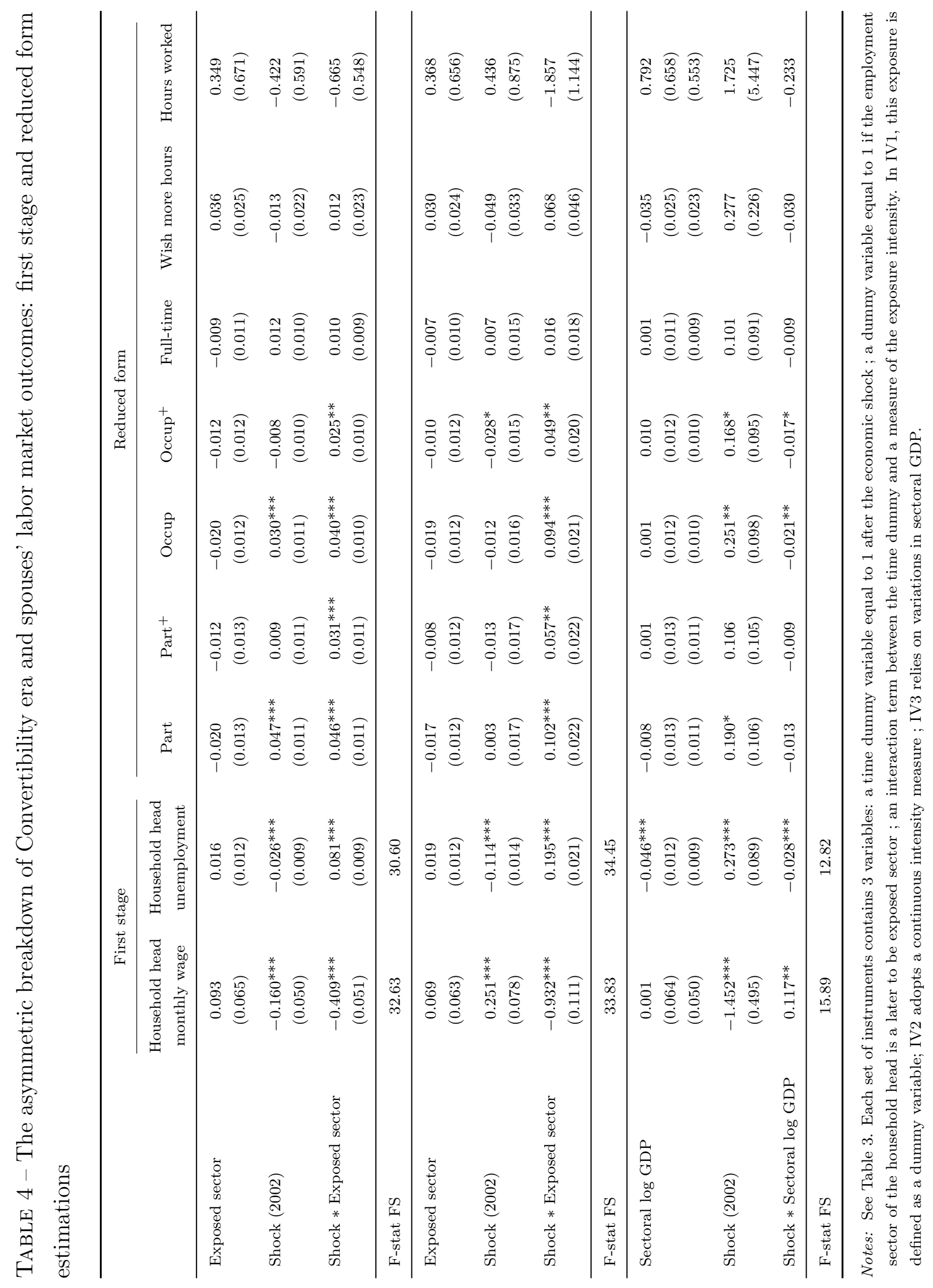


Following the empirical strategy defined in Section 2, equation (5) is estimated using instrumental variables $Z_{i t}$. Control variables $X_{i t}$ are similar to the variables presented for the preliminary analysis above. ${ }^{20}$

Table 4 reports the first stage (left hand side panel) and reduced form results (right hand side panel). Looking at the first stage, the coefficients are strongly significant, and of the expected sign: husbands working in exposed sectors experience a higher decrease in labor income, and a higher probability to lose their job than the other household heads. Correspondingly, the F-stat are all above 10, ruling out the issue of weak instruments. On the whole, the first stage results suggest that the chosen variables qualify for instrumentation. Considering the reduced form, the exposure to the shock is a good explanatory variable for the variation in married women participation. For example, looking at the instrument set $I V 1$, the fact that a husband is working in an exposed sector makes a wife 4.6 percentage points more likely to enter the labor market after 2001. Note that on the opposite, the IV sets correlate poorly with the intensive margin measures of female participation.

Tables 5 and 6 present the results of the estimation of equation (5), using the three sets of instrumental variable and instrumenting for two variables of interest, namely the labor earnings of the household head (Table 5) and his unemployment status (Table 6).

Results displayed in Table 5 are consistent across all specifications of the instruments. We first look at participation at the extensive margin. A 1 percentage point decrease in husband unemployment generates a 0.14 percentage point increase in female labor market participation (column 1). Considering that the household head real wage decreased by $32 \%$ between 2000 and 2002 (see Table 2), this implies that the AWE generated a 4.4 percentage point increase in female participation. This is clearly superior to the 1 percentage point increase observed at the aggregate level, meaning that the AWE is indeed offset by an important discouraged worker effect. After taking into account the possible windfall effect generated by the JJH workfare program, the AWE is slightly smaller, and looses some statistical significance (column 2). However, it still accounts for 1.92 to 2.24 percentage point increase in the labor market participation of married women over the period.

Does this AWE translate into more employment for married women whose husband

\footnotetext{
${ }^{20}$ Only time fixed effects are accounted for differently. Indeed, time already appears within the instrumentation procedure through a pre/post convertibility dummy variable, because the identification relies on sectoral differences before and after the collapse of convertibility. A complete set of semestrial time fixed effects is collinear to the pre/post dummy. Within each of the pre and post periods, time fixed effects are accounted for. Reference categories are October 2001 for the pre period, and October 2002 for the post period.
} 
TABLE 5 - Female labor market participation and their spouse's labor income - IV results

\begin{tabular}{|c|c|c|c|c|c|c|c|}
\hline & \multicolumn{5}{|c|}{ Extensive margin } & \multicolumn{2}{|c|}{ Intensive margin } \\
\hline & (1) & $(2)$ & (3) & $(4)$ & (5) & (6) & (7) \\
\hline & Part & Part $^{+}$ & Occup & Occup $^{+}$ & Full & Wish more hours & Hours worked \\
\hline \multicolumn{8}{|l|}{$I V 1$} \\
\hline \multirow{2}{*}{$\begin{array}{l}\text { Household head } \\
\text { monthly wage }\end{array}$} & $-0.142^{* * *}$ & $-0.071^{* * *}$ & $-0.110^{* * *}$ & $-0.038^{* *}$ & $-0.032^{*}$ & -0.013 & 1.495 \\
\hline & $(0.025)$ & $(0.022)$ & $(0.022)$ & $(0.020)$ & $(0.018)$ & $(0.037)$ & $(0.915)$ \\
\hline \multicolumn{8}{|l|}{$I V 2$} \\
\hline \multirow{2}{*}{$\begin{array}{l}\text { Household head } \\
\text { monthly wage }\end{array}$} & $-0.135^{* * *}$ & $-0.062^{* * *}$ & $-0.110^{* * *}$ & $-0.037^{* *}$ & -0.025 & -0.040 & $1.676^{*}$ \\
\hline & $(0.023)$ & $(0.020)$ & $(0.021)$ & $(0.018)$ & $(0.017)$ & $(0.034)$ & $(0.884)$ \\
\hline \multicolumn{8}{|l|}{ IV3 } \\
\hline \multirow[t]{2}{*}{$\begin{array}{l}\text { Household head } \\
\text { monthly wage }\end{array}$} & $-0.195^{* * *}$ & $-0.068^{* *}$ & $-0.149^{* * *}$ & -0.022 & $-0.054^{*}$ & -0.005 & 1.307 \\
\hline & $(0.041)$ & $(0.033)$ & $(0.035)$ & $(0.029)$ & $(0.029)$ & $(0.056)$ & $(1.469)$ \\
\hline Observations & 18755 & 18755 & 18755 & 18755 & 18755 & 7039 & 7039 \\
\hline
\end{tabular}

Notes: See Table 3 and Table 4 Estimates from linear-probability instrumental regressions with individual fixed effects.

lost labor income with the outburst of the 2001 economic crisis? Occupation (column 3) does indeed increase significantly: a spouse whose husband experienced a 1 percent decrease in his labor income is 0.11 percentage points more likely to actually work at least one hour. The effect shrinks down to 0.04 if we follow the strictest definition of participation and exclude JJH beneficiaries as described above (column 4). Even so, the coefficient remains higher than the baseline specification of Table 3 . Looking at IV1 and $I V 3$, in one third of the cases, the increase in participation results in full time employment (column 5).

Turning to Table 6, similar effects are found when looking at the causal impact of the household head's job loss on the participation of his spouse. A married woman with unemployed husband is 32 to 43 percentage points more likely to enter the labor market if her husband becomes unemployed. Within this period, unemployment increased by 4.3 percentage points (column 1), implying that unemployment generated a 1.38 to 1.85 percentage point increase in married women participation overall. When windfall effects of the JJH workfare program are singled out (column 2), the AWE decreases by one third and IV3 coefficients become insignificant. However, considering IV1 and IV2, the AWE mechanism generates a 1 to 1.25 percentage point increase in female participation. Note that unlike decreases in income, the household head's job loss has no significant positive effect on the probability to work full time for his wife (column 5). 
TABLE 6 - Female labor market participation and their spouse's employment status - IV results

\begin{tabular}{|c|c|c|c|c|c|c|c|}
\hline & \multicolumn{5}{|c|}{ Extensive margin } & \multicolumn{2}{|c|}{ Intensive margin } \\
\hline & (1) & $(2)$ & (3) & (4) & (5) & (6) & (7) \\
\hline & Part & Part $^{+}$ & Occup & Occup $^{+}$ & Full & Wish more hours & Hours worked \\
\hline \multicolumn{8}{|l|}{$I V 1$} \\
\hline \multirow{2}{*}{$\begin{array}{l}\text { Household head } \\
\text { unemployment }\end{array}$} & $0.433^{* * *}$ & $0.289^{* *}$ & $0.353^{* * *}$ & $0.209^{*}$ & 0.069 & 0.287 & -6.158 \\
\hline & $(0.124)$ & $(0.118)$ & $(0.116)$ & $(0.109)$ & $(0.097)$ & $(0.218)$ & $(5.441)$ \\
\hline \multicolumn{8}{|l|}{ IV2 } \\
\hline \multirow{2}{*}{$\begin{array}{l}\text { Household head } \\
\text { unemployment }\end{array}$} & $0.429^{* * *}$ & $0.242^{* *}$ & $0.379 * * *$ & $0.192^{* *}$ & 0.048 & $0.406^{*}$ & -7.631 \\
\hline & $(0.110)$ & $(0.103)$ & $(0.103)$ & $(0.095)$ & $(0.085)$ & $(0.209)$ & $(5.219)$ \\
\hline \multicolumn{8}{|l|}{ IV3 } \\
\hline \multirow[t]{2}{*}{$\begin{array}{l}\text { Household head } \\
\text { unemployment }\end{array}$} & $0.328^{*}$ & 0.124 & $0.306^{*}$ & 0.102 & 0.113 & $0.726^{* *}$ & -11.008 \\
\hline & $(0.174)$ & $(0.168)$ & $(0.164)$ & $(0.155)$ & $(0.143)$ & $(0.363)$ & $(8.648)$ \\
\hline Observations & 18755 & 18755 & 18755 & 18755 & 18755 & 7039 & 7039 \\
\hline
\end{tabular}

Notes: See Table 3 and Table 4 Estimates from linear-probability instrumental regressions with individual fixed effects.

Both Table 5 and Table 6 also display estimates for spouses' labor supply at the intensive margin (column 6 and 7). Here, the sample is reduced to households with an employed spouse in both periods. Compared with the extensive margin, results are less robust across the various specifications. Looking at column 6 of Table 6, an interesting robust causal relation appears between the job loss of the household head and his spouse's desire to work more hours. Indeed, with respect to women whose husband does not change situation, they are twice more likely to declare wishing to work more hours. Interestingly, looking back at Table 5, no such relation appears when husbands experience a decrease in income, suggesting that this additional supply of working hours is driven by leisure substitution between spouses. However, this additional supply of hours does not evolve into an actual increase in working hours (column 7 ). In fact, if anything, the relation goes counter the AWE hypothesis. Indeed, looking back at Table 5, only women whose husband experiences a positive labor income shock are actually likely to work more hours. This suggests that the capacity to keep a job and extend working hours is not randomly assigned with respect to household characteristics. Overall, the results obtained with the IV method in Tables 5 and 6 are higher in magnitude than the results obtained with the simple fixed effect model in Table 3 . 


\subsection{Some evidence on compensation effects}

To what extent does the labor income shock experienced by the household head affect the total household income? To what extent does the added worker effect compensate for this loss?

We provide some suggestive evidence using the specification in equation (8). We reason at the intra-household level, and we focus on the correlation between variations in the labor income of the household head $W_{i t}$, and other income sources $I_{i t}$. $S_{t}$ is a dummy variable standing for the post crisis period, $W_{i t} \times S_{t}$ is an interaction term capturing specific post crisis correlations between the income of the household head and the other income sources. $\mu_{i}$ is an individual fixed effect, and $\phi_{t}$ is a time fixed effect.

$$
I_{i t}=W_{i t} \beta+S_{t} \gamma+W_{i t} \times S_{t} \delta+\mu_{i}+\phi_{t}+\epsilon_{i t}
$$

In Table 7, we first look at the correlation between the variation of the household head's labor income, and the total monthly family income (column 1). A 1 percent decrease in the household head labor income is associated with a 0.37 percent decrease in the total family income. This coefficient is significantly lower than 1 , implying that variations in the income of the household head are at least partially compensated by variations in other income sources.

Next, we focus on the correlation between variations in the labor income of the household head, and variations in other income sources (column 2-8). Clearly, non-labor income is the most sensitive to the variations in the labor income of the household head. A 1 percent income loss is associated with a 0.18 percent increase in the non labor income of a family (column 2). The labor income of other members of the household is far less responsive. If anything, the labor income of other members (spouse excepted) correlates positively with the labor income of the household head (column 3).

Nonetheless, the variation in labor income of the spouse reveals interesting patterns. First of all, the variation in the labor income of married women is negatively correlated with the labor income of her spouse (column 4). Interestingly, adding the interaction term $W_{i t} \times S_{t}$ indicates that the negative correlation exclusively relates to the post 2002 period (column 5), while this was not the case for other income sources. Column 6 suggests that the compensation is stronger whenever the sample is restricted to spouses whose husband experienced a decline in labor income over the period 2000-2002: the correlation appears not to be driven by married women withdrawing from the labor market when their husband finds a job. Unsurprisingly, the correlation is even more negative when 
TABLE 7 - Alternative income sources and the labor income of the household head

\begin{tabular}{|c|c|c|c|c|c|c|c|c|}
\hline & \multirow{2}{*}{$\frac{\begin{array}{c}\text { Family } \\
\text { income }^{a}\end{array}}{(1)}$} & \multirow{2}{*}{$\frac{\begin{array}{c}\text { Non-labor } \\
\text { income }^{b}\end{array}}{(2)}$} & \multirow{2}{*}{$\begin{array}{c}\begin{array}{c}\text { Labor } \\
\text { income }^{c}\end{array} \\
(3)\end{array}$} & \multicolumn{5}{|c|}{ Spouse labor income } \\
\hline & & & & (4) & (5) & (6) & (7) & (8) \\
\hline \multirow[t]{2}{*}{$\begin{array}{l}\text { Household head } \\
\text { Log mthly inc. (W) }\end{array}$} & $0.365^{* * *}$ & $-0.183^{* * *}$ & $0.020^{*}$ & $-0.026^{* *}$ & -0.010 & 0.022 & 0.043 & 0.052 \\
\hline & $(0.014)$ & $(0.015)$ & $(0.011)$ & $(0.011)$ & $(0.013)$ & $(0.022)$ & $(0.029)$ & $(0.032)$ \\
\hline \multirow[t]{2}{*}{ Shock (2002) } & $-0.250^{* * *}$ & -0.057 & -0.058 & $-0.190^{* * *}$ & ${ }^{k}-0.025$ & 0.148 & $0.666^{* * *}$ & $0.804^{* * *}$ \\
\hline & $(0.089)$ & $(0.098)$ & $(0.083)$ & $(0.052)$ & $(0.096)$ & $(0.141)$ & $(0.191)$ & $(0.199)$ \\
\hline \multirow[t]{2}{*}{ Shock $\times W$} & 0.005 & -0.002 & 0.012 & & $-0.030^{* *}$ & $-0.060^{* * *}$ & $-0.076^{* * *}$ & $-0.083^{* * *}$ \\
\hline & $(0.014)$ & $(0.015)$ & $(0.012)$ & & $(0.014)$ & $(0.020)$ & $(0.027)$ & $(0.027)$ \\
\hline Observations & 18755 & 18755 & 18755 & 18755 & 18755 & 14429 & 7864 & 6171 \\
\hline
\end{tabular}

Notes: $* \mathrm{p}<0.1,{ }^{* *} \mathrm{p}<0.05,{ }^{* * *} \mathrm{p}<0.01$. Standard errors in parentheses, clustered at the individual level. All specifications include time and individual fixed effects. ${ }^{a}$ Family income contains all income sources, including the labor income of the household head and his spouse. ${ }^{b}$ Non labor income includes pensions, capital income, remittances, and other income sources. ${ }^{c}$ Labor income of all household members, head and spouse excepted.

the sample is restricted to women whose husband experienced a decline in income, and who are either on the market during the whole period, or entering the labor market after the 2002 economic shock (column 7). Finally, column 8 considers women who are either employed during the full period, or entering an occupation after the shock. The point estimate of 0.08 suggests that when a married woman is/enters on the labor market, and manages to work at least one hour, almost one tenth of the household head's income loss at the time of the crisis is compensated.

\section{$5 \quad$ Robustness analysis}

In this section, we first run a sensitivity analysis with respect to the workfare program JJH. We then perform standard robustness checks to support the validity of our empirical design. To give additional credit to the common trend hypothesis, we run a placebo regression, arbitrarily redefining the date of the shock in October 2001 instead of December 2001. We then test for attrition across waves. Finally, we provide additional evidence supporting the exogeneity of the shock with respect to married women participation decision.

\subsection{Sensitivity analysis}

Within the EPH, JJH beneficiaries are defined as employed. However, the rapid scaling-up and the institutionally explosive context made it difficult to ensure that beneficiaries were 
complying with the work requirements, which may have fostered shirking. Additionally, anecdotal claims report clientelism from the part of municipalities and unions in the granting process. If this is the case, the JJH program plays the role of a time confounder in the causal estimation of the AWE.

This issue should not be too preoccupying. Indeed, in their evaluation of the JJH program, Galasso and Ravallion (2004) insist on the essential role of the program in alleviating poverty and reducing unemployment: more than the half of the JJH participants were originally unemployed, meaning that the windfall effect does not exceed 50 percent of the JJH beneficiaries. Still, we adopt two strategies to disentangle the windfall effect of the program from the measured AWE. First, we use available information in the EPH to redefine as inactive JJH participants that would most likely not seek for a job. Second, we concentrate on relevant subsamples, and show that the AWE also appears in subgroups where the JJH program was not available or requested.

We first redefine JJH beneficiaries as inactive, unless they declared actively looking for a job at least once in the year prior to their participation in the JJH program participation. Of course, such a piece of information is not available for all married women in the panel, so this definition is overly conservative: only $14.7 \%$ of the original JJH beneficiaries qualify to be included into the labor market participating group. Then, taking into account that the working counterpart was mostly enforced after May 2002 (Galasso and Ravallion, 2004), we redefine all beneficiaries entering the program before May 2002 as inactive. We argue that these restrictions select out the beneficiaries that are least likely to comply with the workfare contribution and most likely to shirk and benefit from a windfall effect. If the moral hazard issues are sorted out, the implementation of the workfare program comes down to relaxing the constraint over the demand side.

The first two columns of Table 8 present the results for participation decision and employment probability with respect to husband labor market outcomes, once we restrict participation and occupation definitions. The AWE is still significant, and represents one half to two thirds of the estimates displayed in Table 5.

Alternatively, we now measure the AWE by excluding the households where the wife participates into the JJH program from the sample. The results are presented in Column 3 of Table 8 . The AWE is still showing up, and is far from negligible: a 10 percent decrease in the household head's labor income generates a 0.64 percentage point increase in the probability of his spouse to participate into the labor market. This represents 60 percent of the AWE effect found using the whole sample. However, unlike in the case of Table 5 or 6, this participation does not translate that easily into more employment. In a context of decreasing opportunities, spouses whose husband experiences an income decline or a 
TABLE 8 - Sensitivity analysis using restrictive definitions for participation and occupation

\begin{tabular}{|c|c|c|c|c|c|c|}
\hline & \multicolumn{3}{|c|}{ Dep. Var: Participation } & \multicolumn{3}{|c|}{ Dep. Var: Occupation } \\
\hline & (1) & (2) & (3) & (1) & (2) & (3) \\
\hline \multirow{2}{*}{$\begin{array}{l}\text { Household head } \\
\text { monthly wage }\end{array}$} & $-0.056^{* *}$ & $-0.088^{* * *}$ & $-0.064^{* *}$ & $-0.040^{*}$ & $-0.072^{* * *}$ & -0.035 \\
\hline & $(0.026)$ & $(0.027)$ & $(0.027)$ & $(0.024)$ & $(0.025)$ & $(0.024)$ \\
\hline F-stat FS & 33.78 & 33.78 & 31.57 & 33.78 & 33.78 & 31.57 \\
\hline \multirow{2}{*}{$\begin{array}{l}\text { Household head } \\
\text { unemployment }\end{array}$} & $0.217^{*}$ & $0.322^{* * *}$ & $0.245^{* *}$ & 0.145 & $0.249^{* *}$ & 0.111 \\
\hline & $(0.114)$ & $(0.120)$ & $(0.116)$ & $(0.107)$ & $(0.111)$ & $(0.105)$ \\
\hline F-stat FS & 45.55 & 45.55 & 45.89 & 45.55 & 45.55 & 45.89 \\
\hline Observations & 18755 & 18755 & 18088 & 18755 & 18755 & 18088 \\
\hline
\end{tabular}

Notes: See Table 3 and Table 4 Specification (1): JJH beneficiaries excluded from participation and occupation, unless they happen to have been unemployed prior to JJH program extension. Specification (2): JJH beneficiaries excluded from participation and occupation if they entered the program before May 2002. Instrument set is $I V 1$. IV2 set yields similar results. With $I V 3$, coefficients are of similar magnitude, but error terms are higher. Specification (3): JJH beneficiaries excluded from participation.

job loss are not more likely to actually find a job than spouses with more stable husbands, which mean that they enter unemployment without benefiting from the JJH program. This result gives further evidence in favor of the poverty and unemployment alleviation role played by the JJH (Galasso and Ravallion, 2004): married women ineligible or unable to benefit from the JJH express willingness to supply labor, but cannot cope against the shock affecting their household.

\subsection{Placebo test}

If the common trend assumption hold, the AWE should not exist before the actual outburst of the crisis. We thus perform a placebo test arbitrarily redefining the Convertibility collapse to happen in October instead of December 2001. Table 9 is generated by running the exact same instrumental definition and estimation procedures presented in Section 2 , with this new definition of the Convertibility collapse. Within this estimation framework, we find that variations in the labor outcomes of the household head do not affect female participation. The top (respectively bottom) panel of Table 9 presents results instrumenting for the labor income (respectively the occupation status) of the household head. In both panels, all the displayed coefficients are smaller than the coefficients reported in Tables 5 and 6. All coefficients (but one) do not significantly differ from 0 at the $10 \%$ 
level.

TABLE 9 - Placebo test: the Convertibility arbitrarily ends before October 2001

\begin{tabular}{|c|c|c|c|c|c|c|c|}
\hline & \multicolumn{5}{|c|}{ Extensive margin } & \multicolumn{2}{|c|}{ Intensive margin } \\
\hline & (1) & $(2)$ & (3) & (4) & $(5)$ & (6) & (7) \\
\hline & Part & Part ${ }^{+}$ & Occup & Occup $^{+}$ & Full & Wish more hours & Hours worked \\
\hline \multicolumn{8}{|l|}{$I V 1$} \\
\hline \multirow{2}{*}{$\begin{array}{l}\text { Household head } \\
\text { monthly wage }\end{array}$} & -0.065 & -0.063 & -0.045 & -0.044 & 0.037 & 0.034 & -0.089 \\
\hline & $(0.039)$ & $(0.039)$ & $(0.035)$ & $(0.035)$ & $(0.035)$ & $(0.084)$ & $(2.914)$ \\
\hline \multicolumn{8}{|l|}{$I V^{2}$} \\
\hline \multirow{2}{*}{$\begin{array}{l}\text { Household head } \\
\text { monthly wage }\end{array}$} & -0.049 & -0.043 & -0.030 & -0.025 & 0.036 & 0.005 & 0.852 \\
\hline & $(0.036)$ & $(0.036)$ & $(0.032)$ & $(0.032)$ & $(0.032)$ & $(0.081)$ & $(2.958)$ \\
\hline \multicolumn{8}{|l|}{ IV3 } \\
\hline \multirow{2}{*}{$\begin{array}{l}\text { Household head } \\
\text { monthly wage }\end{array}$} & -0.150 & -0.120 & $-0.146^{*}$ & -0.116 & -0.097 & 0.030 & -9.186 \\
\hline & $(0.091)$ & $(0.085)$ & $(0.087)$ & $(0.080)$ & $(0.075)$ & $(0.165)$ & $(8.818)$ \\
\hline Observations & 20281 & 20281 & 20281 & 20281 & 20281 & 9576 & 9576 \\
\hline \multicolumn{8}{|l|}{$I V 1$} \\
\hline \multirow{2}{*}{$\begin{array}{l}\text { Household head } \\
\text { unemployment }\end{array}$} & 0.315 & 0.295 & 0.198 & 0.179 & -0.169 & -0.175 & -0.587 \\
\hline & $(0.200)$ & $(0.198)$ & $(0.181)$ & $(0.177)$ & $(0.179)$ & $(0.397)$ & $(13.744)$ \\
\hline \multicolumn{8}{|l|}{ IV2 } \\
\hline \multirow[t]{2}{*}{$\begin{array}{l}\text { Household head } \\
\text { unemployment }\end{array}$} & 0.243 & 0.207 & 0.130 & 0.093 & -0.166 & -0.041 & -4.806 \\
\hline & $(0.187)$ & $(0.185)$ & $(0.168)$ & $(0.165)$ & $(0.166)$ & $(0.381)$ & $(13.304)$ \\
\hline \multicolumn{8}{|l|}{ IV3 } \\
\hline \multirow{2}{*}{$\begin{array}{l}\text { Household head } \\
\text { unemployment }\end{array}$} & 0.292 & 0.226 & 0.254 & 0.189 & 0.126 & 0.078 & 3.852 \\
\hline & $(0.187)$ & $(0.184)$ & $(0.174)$ & $(0.169)$ & $(0.159)$ & $(0.287)$ & $(11.160)$ \\
\hline Observations & 20281 & 20281 & 20281 & 20281 & 20281 & 9576 & 9576 \\
\hline
\end{tabular}

Notes: See Table 3 and Table 4 Estimates from linear-probability instrumental regressions with individual fixed effects.

\subsection{Attrition}

As for any panel survey, attrition is of potential concern. Notably, The Argentina statistical intitute INDEC reports some troubles in collecting the data for interviewers in nine areas of the Greater Buenos Aires after the outburst of the economic and social turmoil of December 2001. According to their estimations, insecurity on field accounts for 2.2 percentage point decrease in GBA sample's representativeness. Random assignment of these social troubles is unlikely. Mismatching represents an other concern of attrition bias. As 
mentioned earlier, in its sampling strategy, EPH uses a geographical criteria, following household structures rather than specific households. As a consequence, mismatching can lead to an attrition bias, especially if decision to move in or out is determined by economic environment - which is likely to be the case.

A simple test for panel attrition consists in computing group-means for a range of outcomes of interest: husband unemployment, husband log income for each year $t=$ $1998,1999, \ldots 2002$ separately. Individuals are grouped according to their stage $j(j=$ $1,2,3,4)$ in EPH survey. Significant differences in means between these different groups would give support to the attrition bias hypothesis.

Formally, we use the enlarged sample and test for mean equalities: $\bar{W}_{1}=\bar{W}_{2}=$ $\bar{W}_{3}=\bar{W}_{4}$ : regressing it on $j$ dummies for waves, for each $t$ between 1998 and 2002:

$$
W_{i}=\alpha+\sum_{j=1}^{4} \beta_{j} w_{i j}+\epsilon_{i}
$$

The constant term $\alpha$ indicates mean outcome for new entrants in survey, and the coefficients measure deviation to this mean for participants in waves 2,3 , and 4 of the same year exposed to same economic conditions. Results reported in Table 10 suggest that panel attrition is limited. Regardless of the year, the household head labor market outcomes exhibit no pattern of attrition from wave to wave. ${ }^{21}$

\subsection{Superior information}

We now provide additional evidence supporting the exogeneity of the negative shock with respect to the participation decision of married women. In this section, we consider the fact that households may have accessed superior information, and consequently given an anticipated response to the shock. As previously stated, the international statistical agencies did not forecast the depth of the Argentine economic crisis. As an additional piece of evidence, we re-run the specification (7), but we replace the interest variables with their forward values. The idea behind this specification is that if the superior information hypothesis holds, part of the adjustment should happen before the negative shock actually hits the households.

\footnotetext{
${ }^{21}$ Alternatively, we regress the probability for a household to drop out from the sample before the fourth wave on the labor income, and the employment status of the household head, controlling for time fixed effects. We find no difference in the probability of dropping out: in the period before they drop out of the sample, dropouts are not different from non dropouts with respect to key interest variables. The results (not reported here) are available upon request.
} 
TABLE 10 - Mean test for sample attrition analysis

\begin{tabular}{|c|c|c|c|c|c|c|}
\hline & \multicolumn{3}{|c|}{ Dep. var.: husb. monthly income } & \multicolumn{3}{|c|}{ Dep. var: husb. unemployment } \\
\hline & EPH 2000 & EPH 2001 & EPH 2002 & EPH 2000 & EPH 2001 & EPH 2002 \\
\hline Second wave participant & $\begin{array}{r}-0.003 \\
(0.038)\end{array}$ & $\begin{array}{c}-0.023 \\
(0.043)\end{array}$ & $\begin{array}{r}-0.095 \\
(0.061)\end{array}$ & $\begin{array}{c}0.001 \\
(0.006)\end{array}$ & $\begin{array}{c}0.011 \\
(0.007)\end{array}$ & $\begin{array}{c}0.014 \\
(0.010)\end{array}$ \\
\hline Third wave participant & $\begin{array}{c}-0.043 \\
(0.038)\end{array}$ & $\begin{array}{r}-0.020 \\
(0.043)\end{array}$ & $\begin{array}{r}-0.078 \\
(0.061)\end{array}$ & $\begin{array}{c}0.004 \\
(0.006)\end{array}$ & $\begin{array}{c}0.006 \\
(0.007)\end{array}$ & $\begin{array}{c}0.015 \\
(0.010)\end{array}$ \\
\hline Fourth wave participant & $\begin{array}{r}-0.021 \\
(0.040)\end{array}$ & $\begin{array}{r}-0.069 \\
(0.045)\end{array}$ & $\begin{array}{c}-0.063 \\
(0.062)\end{array}$ & $\begin{array}{c}0.001 \\
(0.006)\end{array}$ & $\begin{array}{c}0.010 \\
(0.007)\end{array}$ & $\begin{array}{c}0.016 \\
(0.010)\end{array}$ \\
\hline Constant & $\begin{array}{l}5.875^{* * *} \\
(0.028)\end{array}$ & $\begin{array}{l}5.669^{* * *} \\
(0.031)\end{array}$ & $\begin{array}{l}5.191^{* * *} \\
(0.051)\end{array}$ & $\begin{array}{l}0.085^{* * *} \\
(0.005)\end{array}$ & $\begin{array}{l}0.101^{* * *} \\
(0.005)\end{array}$ & $\begin{array}{l}0.122^{* * *} \\
(0.008)\end{array}$ \\
\hline Observations & 16184 & 15945 & 12936 & 16184 & 15945 & 12936 \\
\hline
\end{tabular}

TABLE 11 - Test for superior information

\begin{tabular}{|c|c|c|c|c|c|c|c|}
\hline & \multicolumn{5}{|c|}{ Extensive margin } & \multicolumn{2}{|c|}{ Intensive margin } \\
\hline & $(1)$ & $(2)$ & (3) & $(4)$ & $(5)$ & (6) & $(7)$ \\
\hline & Part & Part $^{+}$ & Occup & Occup $^{+}$ & Full-time & Wish more hours & Hours worked \\
\hline \multirow{2}{*}{$\begin{array}{l}\text { Household head } \\
\text { monthly wage }\end{array}$} & 0.000 & -0.000 & -0.002 & -0.002 & -0.003 & 0.003 & -0.057 \\
\hline & $(0.003)$ & $(0.003)$ & $(0.003)$ & $(0.002)$ & $(0.002)$ & $(0.006)$ & $(0.134)$ \\
\hline \multirow[t]{2}{*}{$\begin{array}{l}\text { Household head } \\
\text { unemployment }\end{array}$} & -0.004 & -0.000 & 0.017 & 0.020 & 0.015 & -0.006 & 0.311 \\
\hline & $(0.017)$ & $(0.017)$ & $(0.015)$ & $(0.015)$ & $(0.014)$ & $(0.035)$ & $(0.787)$ \\
\hline Observations & 11971 & 11971 & 11971 & 11971 & 11971 & 4965 & 4965 \\
\hline
\end{tabular}

Notes: See Table 3 Estimates from linear-probability regressions with individual fixed effects.

Table 11 indicates that no correlation exists between the labor supply of a married woman and the labor market outcomes of her husband observed during the following semester. $^{22}$

\subsection{Group manipulation}

Regarding the exogeneity assumption, a second concern arises with the possibility of group manipulation: namely, the fact that household heads working in the most exposed sectors may switch sector to avoid the negative effects of the crisis on their labor out-

\footnotetext{
${ }^{22}$ In addition, we re-run the IV specification (5). At the extensive margin, the results (not reported) are not significantly different from 0 .
} 
comes. Unsurprisingly, household heads do indeed change sector across periods. Overall, between October 2000 and October 2002, 8.08\% of the sample observations report that the household head switches from a protected towards an exposed sector $(3.73 \%)$ or vice versa $(4.35 \%)$. Though the phenomenon is not massive, whether these changes may be endogenous to female participation or not is a relevant question. In what follows, we first provide the intuition behind the possible bias. We then provide empirical evidence suggesting that a bias related to group manipulation should be ruled out.

Regarding the first stage regression, the existence of a strategic group manipulation could bias the negative relation between the husband income and the sector's exposure towards 0 (in case of a reverse causality, where only the least exposed actually stay involved in their sector of origin). Alternatively, the bias could be of an undetermined sign, if unobserved characteristics determine both the capacity of a household head to change sector and his income variation. In any case, the group manipulation is mostly problematic if these unobserved characteristics simultaneously affect the decision of married women to supply labor. ${ }^{23}$ In this case, the sector of the household head is endogenous to the participation decision of the spouse. Under this hypothesis, the estimates would be biased. Theoretically, the sign of the bias is unclear, and mainly relates to the degree of substitution and complementarity existing between the two coping strategies, i.e. the added worker and the change in sector of activity. The estimates will be biased upward if the strategies are substitutes (husbands who switch sectors do so because their wives are unable or unwilling to supply labor). The bias will go in the opposite direction if the strategies are complements: spouses whose husband switch sector are also more able or willing to supply labor. The empirical literature on household vulnerability clearly favors the complementarity argument (Lokshin and Yemtsov, 2004): while some households benefit from a wide panel of adjustment strategies, others fail to compensate for negative shocks. For example, in our case, the fact to possess an extended network could enable a household head to switch sector and simultaneously his wife to supply additional hours or get a job.

We check the robustness of our results following three intuitions. First, if changing sector really matters for husbands' outcomes and female participation, it should already be enhanced by the first stage and reduced form regressions of Table 4 (Section 44). Indeed, as explained in Section 2, the instrument sets already include a dummy indicating whether the sector of activity is a protected or exposed one. In the first stage, the effect

\footnotetext{
${ }^{23}$ These unobserved characteristics do not need to vary with time. Although they are time-invariant, they are not differentiated out with the individual component because their effect itself is time-varying. These characteristics come into play once the negative shock hits, and can play the role of a time-varying confounder.
} 
of a change in sector type on the income of the household head is thus taken into account. As indicated by the point estimate for the variable Exposed sector in Table 4 , on average, this change has no effect on the income or employment status of the household head. In addition, the reduced form regressions suggest that there is no correlation between shifts in sectors and married women participation, even through the channel of their husband's labor market outcomes. These results thus convey a first convincing piece of evidence suggesting that changes in sectors are exogenous to female participation.

Second, we take advantage of the fact that switching sector is a common event for individuals in normal times as well. We compare the household heads who switch sector during the 2002 events with those who switch in the previous periods. Our goal is to see whether the post Convertibility switchers have specific characteristics with respect to their counterparts in normal times, that would then strategically interact with the added worker effect. We regress the probability to change sector on a series of individual and occupation-specific characteristics at baseline: age, education, number of children and elderly in the household, home-ownership, employment status (owner, self employed, wage earner), firm size, task qualification, stability of the job. We allow these characteristics to have a specific effect after October 2001. In line with expectation, the probit results (not reported here) show that overall, household heads changing sectors tend to be qualified wage earners with jobs limited on duration at baseline. However, no observed individual or occupation-specific characteristic allows to distinguish individuals switching sector with respect to the timing of the Convertibility crisis. This supports our view that the possibility for household heads to change sector does not come at costs of our exogeneity assumption.

Finally, as a third robustness check, we take into consideration the extreme hypothesis that the households whose husband switches sector entirely drive the results. We run the analysis again excluding the switchers from our sample. From Table 12, we see that the results are robust to the exclusion of the households whose head switches sector between October 2001 and May 2002. ${ }^{24}$

\footnotetext{
${ }^{24}$ In addition, we re-run the IV specification (5) (not reported here). When we instrument for the variations in the household head monthly wage, the results are very similar to the main results of Table 5 When instrumenting for the unemployment status, the magnitude of the point estimates is higher. In this case, group manipulation may be responsible for a downward bias. This gives credit to the hypothesis of complementarity between coping strategies.
} 
TABLE 12 - Test for group manipulation

\begin{tabular}{|c|c|c|c|c|c|c|c|}
\hline & \multicolumn{5}{|c|}{ Extensive margin } & \multicolumn{2}{|c|}{ Intensive margin } \\
\hline & $(1)$ & $(2)$ & (3) & $(4)$ & $(5)$ & $(6)$ & $(7)$ \\
\hline & Part & Part $^{+}$ & Occup & Occup ${ }^{+}$ & Full-time & Wish more hours & Hours worked \\
\hline \multirow[t]{2}{*}{$\begin{array}{l}\text { Household head } \\
\text { monthly wage }\end{array}$} & $-0.016^{* * *}$ & $-0.012^{* * *}$ & $-0.011^{* * *}$ & $-0.007^{* * *}$ & -0.003 & $-0.011^{* *}$ & 0.001 \\
\hline & $(0.002)$ & $(0.002)$ & $(0.002)$ & $(0.002)$ & $(0.002)$ & $(0.004)$ & $(0.110)$ \\
\hline \multirow{2}{*}{$\begin{array}{l}\text { Household head } \\
\text { unemployment }\end{array}$} & $0.071^{* * *}$ & $0.052^{* * *}$ & $0.048^{* * *}$ & $0.029^{* *}$ & 0.014 & $0.058^{* *}$ & 0.049 \\
\hline & $(0.014)$ & $(0.014)$ & $(0.013)$ & $(0.013)$ & $(0.012)$ & $(0.027)$ & $(0.661)$ \\
\hline Observations & 17239 & 17239 & 17239 & 17239 & 17239 & 7300 & 7300 \\
\hline
\end{tabular}

Notes: See Table 3 Estimates from linear-probability regressions with individual fixed effects.

\section{$6 \quad$ Heterogeneity analysis}

This section provides an insight into heterogeneous effects at work beyond the average AWE. Several assumptions can be made regarding the relevant sources of heterogeneity. First, in a traditional labor supply perspective, women in childless couples should have a preference for working, or should be less constrained in their labor supply decisions. As a consequence, their AWE should exceed the AWE for women with children. On the other hand, according to a more collective view of the household (Lundberg et al., 1997), all else being equal, and controlling for the variation in the number of children within the household, women with children could enter relatively more the labor market if their husband experiences a decline in income, in order to smooth their children's consumption. Second, the AWE should be negatively correlated with the holding of assets. Though information on savings is not available within this survey, the life cycle theory suggests that individuals smooth their consumption over their lifetime, implying that savings are formed in an intermediate phase of the life cycle. The AWE is expected to vary according to the age category of the household (Starr, 2013). Third, income utility marginally decreases. Correspondingly, the wealth effect associated with a given temporary income loss should be higher if the household belongs to the first income quartile at baseline, than in case it pertains to the richest quartile (MaCurdy, 1985). Following this idea, the AWE should be smaller in case the household owns its dwelling. Finally, all else being equal, the AWE should be related to the level of human capital accumulated by married women. On the one hand, the AWE should be higher when wives are more educated, because educated wives should be prone to work and find better opportunities. On the other hand, their participation level is already high relatively to the less educated women, 
and their reservation wage is higher, which is a barrier to entry on the informal labor market.

In order to answer these empirical questions, household head's labor market outcomes - i.e. labor income and employment status - should be interacted with a series of characteristics that are allegedly a source of heterogeneity. In our case, an issue appears, in so far household head's labor market outcomes are instrumented. Following Wooldridge $(2002)^{25}$, the interaction terms are thus endogenous, non linear variables. In Wooldridge's words, a 'forbidden regression' would arise if we interact the exogenous variables with the predicted value of our instrumented variable of interest. As in the case of the variable of interest, all of the interaction terms have to be instrumented by an interaction between the exogenous variables and the instruments. For example, a correct estimation of the heterogeneous effect of baseline home ownership implies to instrument husband's income using the set of instruments $I V 1$, and to instrument the interaction between husband's income and the exogenous ownership dummy with the IV1 set itself interacted with the home ownership dummy. ${ }^{26}$

Results are presented in Table 13 . For the sake of concision, we only display results using the IV1 set of instruments, and participation decision at the extensive margin. Only results using husband's variation in income are presented, because regressions instrumenting for husband's variation in employment status is subject to weakness.

Looking at Panel A, the AWE does not differ according to age categories. There is no evidence that younger couples use relatively more labor market coping strategies because they cannot cope against unexpected shocks using savings. Panel B and C show that the wealth effects associated with the shock varies indeed according to the level of income at baseline, or according to home ownership. Women belonging to the richest quartile in 2000-2001 are less likely to enter the labor market and find a job in case their husband is hit by a shock than women belonging to quartiles 1, 2 and 3. Panel $\mathrm{C}$ indicates that in case households own their dwelling, the AWE is divided by half. Panel D displays heterogeneity results according to education attainment. The AWE is more important for lower educational degrees, however this heterogeneity disappears when JJH beneficiaries are redefined as non-participants. Panel E displays the differences in AWE for childless couples, couples with at least one child under compulsory schooling age, and couples with at least one child above schooling age and under 18. Surprisingly, while women with young children react similarly to unexpected shocks in their husband's income, women

\footnotetext{
${ }^{25}$ Section 9.5 pp. $236-7$.

${ }^{26}$ Because of this complex instrumentation procedure, we study each heterogeneity source separately. As a consequence, the heterogenous effect of income quartile at baseline is likely to partly capture the heterogeneous effects of human capital.
} 
TABLE 13 - Heterogeneity analysis

\begin{tabular}{|c|c|c|c|c|c|}
\hline & Part & Part $^{+}$ & Occup & Occup $^{+}$ & Full-time \\
\hline \multicolumn{6}{|l|}{ Panel A : Age, woman } \\
\hline Husb. monthly income & $\begin{array}{l}-0.0189 \\
(-0.70)\end{array}$ & $\begin{array}{l}-0.0405 \\
(-1.51)\end{array}$ & $\begin{array}{l}-0.0230 \\
(-0.89)\end{array}$ & $\begin{array}{l}-0.0446^{*} \\
(-1.76)\end{array}$ & $\begin{array}{l}0.0114 \\
(0.49)\end{array}$ \\
\hline$\times$ aged 1629 & $\begin{array}{l}-0.0142 \\
(-0.56)\end{array}$ & $\begin{array}{l}0.0150 \\
(0.60)\end{array}$ & $\begin{array}{l}-0.00215 \\
(-0.09)\end{array}$ & $\begin{array}{l}0.0271 \\
(1.14)\end{array}$ & $\begin{array}{l}-0.0205 \\
(-0.93)\end{array}$ \\
\hline$\times$ aged 3044 & $\begin{array}{l}-0.00477 \\
(-0.22)\end{array}$ & $\begin{array}{c}0.0167 \\
(0.76)\end{array}$ & $\begin{array}{l}0.00775 \\
(0.36)\end{array}$ & $\begin{array}{l}0.0292 \\
(1.40) \\
\end{array}$ & $\begin{array}{l}-0.00900 \\
(-0.47)\end{array}$ \\
\hline \multicolumn{6}{|c|}{ Panel B : Homeownership } \\
\hline Husb. monthly income & $\begin{array}{l}-0.119^{* * *} \\
(-4.67)\end{array}$ & $\begin{array}{l}-0.0667^{* *} \\
(-2.82)\end{array}$ & $\begin{array}{l}-0.0925^{* * *} \\
(-3.99)\end{array}$ & $\begin{array}{l}-0.0403^{*} \\
(-1.91)\end{array}$ & $\begin{array}{l}-0.0356^{*} \\
(-1.89)\end{array}$ \\
\hline$\times$ owner & $\begin{array}{l}0.0587^{* * *} \\
(3.82)\end{array}$ & $\begin{array}{l}0.0302^{* *} \\
(2.13)\end{array}$ & $\begin{array}{l}0.0469^{* * *} \\
(3.36)\end{array}$ & $\begin{array}{l}0.0184 \\
(1.46)\end{array}$ & $\begin{array}{l}0.0182 \\
(1.61)\end{array}$ \\
\hline \multicolumn{6}{|c|}{ Panel C: HH income quartile at baseline } \\
\hline Husb. monthly income & $\begin{array}{l}0.0201 \\
(0.98)\end{array}$ & $\begin{array}{l}0.0263 \\
(1.29)\end{array}$ & $\begin{array}{l}0.0454^{* *} \\
(2.32)\end{array}$ & $\begin{array}{l}0.0516^{* *} \\
(2.69)\end{array}$ & $\begin{array}{l}0.0283 \\
(1.46)\end{array}$ \\
\hline$\times$ income Q1 & $\begin{array}{l}-0.0388^{*} \\
(-1.84)\end{array}$ & $\begin{array}{l}-0.0419^{* *} \\
(-1.99)\end{array}$ & $\begin{array}{l}-0.0568^{* *} \\
(-2.83)\end{array}$ & $\begin{array}{l}-0.0599^{* *} \\
(-3.05)\end{array}$ & $\begin{array}{l}-0.0342^{*} \\
(-1.74)\end{array}$ \\
\hline$\times$ income Q2 & $\begin{array}{l}-0.0566^{* *} \\
(-2.60)\end{array}$ & $\begin{array}{l}-0.0580^{* *} \\
(-2.67)\end{array}$ & $\begin{array}{l}-0.0735^{* * *} \\
(-3.48)\end{array}$ & $\begin{array}{l}-0.0749^{* * *} \\
(-3.61)\end{array}$ & $\begin{array}{l}-0.0401^{*} \\
(-1.95)\end{array}$ \\
\hline$\times$ income Q3 & $\begin{array}{l}-0.0178 \\
(-0.79)\end{array}$ & $\begin{array}{l}-0.0211 \\
(-0.94)\end{array}$ & $\begin{array}{l}-0.0394^{*} \\
(-1.84)\end{array}$ & $\begin{array}{l}-0.0428^{* *} \\
(-2.01)\end{array}$ & $\begin{array}{l}-0.0253 \\
(-1.16)\end{array}$ \\
\hline \multicolumn{6}{|c|}{ Panel D: Education, woman } \\
\hline Husb. monthly income & $\begin{array}{l}0.0532^{* *} \\
(2.73)\end{array}$ & $\begin{array}{l}-0.00928 \\
(-0.49)\end{array}$ & $\begin{array}{l}0.0381^{* *} \\
(2.10)\end{array}$ & $\begin{array}{l}-0.0243 \\
(-1.40)\end{array}$ & $\begin{array}{l}0.00898 \\
(0.52)\end{array}$ \\
\hline$\times$ primary degree & $\begin{array}{l}-0.0679^{* * *} \\
(-4.06)\end{array}$ & $\begin{array}{l}-0.00970 \\
(-0.60)\end{array}$ & $\begin{array}{l}-0.0487^{* *} \\
(-3.14)\end{array}$ & $\begin{array}{l}0.00951 \\
(0.64)\end{array}$ & $\begin{array}{l}-0.0153 \\
(-1.03)\end{array}$ \\
\hline$\times$ secondary degree & $\begin{array}{l}-0.0544^{* * *} \\
(-4.20)\end{array}$ & $\begin{array}{l}-0.00902 \\
(-0.72)\end{array}$ & $\begin{array}{l}-0.0394^{* *} \\
(-3.27)\end{array}$ & $\begin{array}{l}0.00593 \\
(0.52)\end{array}$ & $\begin{array}{l}-0.0124 \\
(-1.07)\end{array}$ \\
\hline \multicolumn{6}{|l|}{ Panel E: Children } \\
\hline Husb. monthly income & $\begin{array}{l}-0.0919^{* *} \\
(-3.11)\end{array}$ & $\begin{array}{l}-0.0667^{* *} \\
(-2.29)\end{array}$ & $\begin{array}{l}-0.0563^{* *} \\
(-2.07)\end{array}$ & $\begin{array}{l}-0.0310 \\
(-1.19)\end{array}$ & $\begin{array}{l}-0.0376 \\
(-1.53)\end{array}$ \\
\hline$\times$ child under 5 & $\begin{array}{l}0.0153 \\
(1.33)\end{array}$ & $\begin{array}{l}0.00866 \\
(0.76)\end{array}$ & $\begin{array}{l}0.00317 \\
(0.30)\end{array}$ & $\begin{array}{l}-0.00352 \\
(-0.35)\end{array}$ & $\begin{array}{l}0.00478 \\
(0.50)\end{array}$ \\
\hline$\times$ child above 5 & $\begin{array}{l}0.0468^{* *} \\
(2.43)\end{array}$ & $\begin{array}{l}0.0335^{*} \\
(1.77)\end{array}$ & $\begin{array}{l}0.0319^{*} \\
(1.81)\end{array}$ & $\begin{array}{l}0.0187 \\
(1.10)\end{array}$ & $\begin{array}{l}0.0240 \\
(1.50)\end{array}$ \\
\hline \multicolumn{6}{|c|}{ Panel F: Husb. gets U benefits } \\
\hline Husb. monthly income & $\begin{array}{l}-0.146^{* * *} \\
(-5.77)\end{array}$ & $\begin{array}{l}-0.0722^{* *} \\
(-3.22)\end{array}$ & $\begin{array}{l}-0.113^{* * *} \\
(-4.96)\end{array}$ & $\begin{array}{l}-0.0391^{*} \\
(-1.95)\end{array}$ & $\begin{array}{l}-0.0332^{*} \\
(-1.77)\end{array}$ \\
\hline$\times \mathrm{U}$ benefits & $\begin{array}{l}0.111^{* * *} \\
(4.37)\end{array}$ & $\begin{array}{l}0.0640^{* *} \\
(2.81)\end{array}$ & $\begin{array}{l}0.0685^{* *} \\
(3.11)\end{array}$ & $\begin{array}{l}0.0219 \\
(1.13)\end{array}$ & $\begin{array}{l}0.0158 \\
(0.90)\end{array}$ \\
\hline Observations & 18755 & 8755 & 18755 & 8755 & 18755 \\
\hline
\end{tabular}

Notes: See Table 3 and 4 Instruments set is IV1. Because of the complex instrumentation procedure involving endogenous non linear variables, each source of heterogeneity is analysed in a separate regression. When categories are not binary, reference categories are: age 45-59, superior degree, income Q4, childless couple. 
with children above 5 have a significantly lower AWE. Finally, Panel F indicates that the AWE is significantly smaller for women whose husband experiences a decrease in labor income, but is entitled to unemployment insurance or compensation. ${ }^{27}$

\section{Conclusion}

So far, the existing literature on the added worker effect has answered separately two main questions: (i) do households whose head is hit by an idiosyncratic shock - e.g. unexpected plant closures in developed countries, or climate shocks in developing countries - respond by sending additional workers on the labor market? and (ii) in downward business cycles, is the AWE prevailing over the discouraged worker effect at the aggregate level? This paper fills the gap between the two literatures and develops an original empirical strategy to assess the existence and extent of the added-worker shock coping strategy in the case of an aggregate shock and a macro discouragement effect. Intra-household market oriented strategies are tricky to measure, because in normal times spouses' labor supply is jointly determined, implying that the decision of each spouse is endogenous to the decision of the other spouse. The dramatic collapse of the convertibility era generates an aggregate shock presenting asymmetries with respect to economic sectors. This natural experiment framework is used to instrument for the household head's endogenous labor market outcomes. Results points out that even when discouragement prevails at the aggregate level, there is evidence of an added-worker effect.

In the Argentine case, this AWE is far from negligible. Married women whose spouse experiences a 30 percent decrease in monthly wage (which correspond to the sample mean) are 3 percentage points more likely to enter the labor market. When a husband looses his job, his spouse increases her participation rate by almost 2 percentage points. The magnitude of this effect reflects the fact that the Argentine state relaxes the demand side of the labor market by offering workfare programs paid below the market wage. As a robustness check, we redefined program participants as inactive if they do not work the legal amount of time to be entitled to the program, or if they do not declare wishing to work more hours, in order to select out the potential windfall effect created by the program. The AWE still accounts for a 2 percent increase in female participation over the period. In line with intuition, this AWE is nonetheless slightly inferior to the

\footnotetext{
${ }^{27}$ This result further supports the view that the extra labor supplied by married women is the consequence of an income effect, and not the result of spouses' joint preference for leisure. Married women do not enter the labor market to avoid spending time home when their spouse is unemployed, but to compensate for the income loss.
} 
one observed during upward business cycle by Cerrutti (2000), even after controlling for the changes in macroeconomic opportunities over the period. A preliminary analysis at the intensive margin displays less robust patterns of an "added hours effect" from the part of spouses whose husband undergoes a wage decrease or a job loss. Finally, in line with intuition, the AWE proves to be heterogeneous with respect to home ownership, household income quartile, education degree, husband's unemployment insurance, and the presence of children within the household at baseline.

In a broader perspective, this paper contributes to a recent focus shift in labor supply studies towards a better understanding of the role of labor supply in mitigating uncertainty within households over the lifetime. Perhaps surprisingly, shock coping is still an essential role of the family. Highlighting the existence of a non negligible AWE is the first step towards a better understanding of intra household coping mechanisms in emerging economies with embryonic social safety nets. Future work will have to assess the effectiveness of this AWE in mitigating the impact of the economic downturn. In addition, a complementary aspect of the AWE is whether the additional workforce actually returns to inactivity once lost income has been compensated for. From 2003 onwards, Argentine economy experienced a sudden and radical upward cycle, as displayed in Figure 1. A possible extension to present work would be to document the decisions of married women labor supply at the intra-household level, in order to assess whether the added workers tend to stay in or leave the workforce in a context of drastic economical improvement. Overall, a correct identification of the interrelations between primary and secondary earners' wages, as well as the indirect effects of this intra-household insurance scheme have important policy implications. The literature on female labor supply generally proposes alternative welfare fallouts: female participation increases bargaining power, affecting income allocation between members, but also leads to precarious positions and overwork (Lim, 2000; Klasen and Pieters, 2012). Design and implementation of welfare programs have to interfere intelligently in these existing mechanisms. 


\section{References}

Ayhan, S. (2014). How Do Married Women Respond When Their Husbands Lose Their Jobs? Evidence from Turkey During the Recent Crisis. Mimeo.

Beegle, K., Dehejia, R. H., and Gatti, R. (2006). Child Labor and Agricultural Shocks. Journal of Development Economics, 81(1):80-96.

Bingley, P. and Walker, I. (2001). Household Unemployment and the Labour Supply of Married Women. Economica, 68(270):157-186.

Blundell, R. and Macurdy, T. (1999). Chapter 27 Labor Supply: A Review of Alternative Approaches. In Ashenfelter, O. C. and Card, D., editors, Handbook of labor economics, volume 3, Part A of Handbook of Labor Economics, pages 1559 - 1695. Elsevier.

Cerrutti, M. (2000). Economic Reform, Structural Adjustment and Female Labor Force Participation in Buenos Aires, Argentina. World Development, 28(5):879-891.

Congregado, E., Golpe, A. A., and van Stel, A. (2011). Exploring the big Jump in the Spanish Unemployment Rate: Evidence on an 'Added-worker' Effect. Economic Modelling, 28(3):1099-1105.

Cullen, J. B. and Gruber, J. (2000). Does Unemployment Insurance Crowd out Spousal Labor Supply? Journal of Labor Economics, 18(3):546-572.

Duflo, E. and Udry, C. (2004). Intrahousehold Resource Allocation in Cote d'Ivoire: Social Norms, Separate Accounts and Consumption Choices. Working Paper 10498, National Bureau of Economic Research.

Dynarski, M. and Sheffrin, S. M. (1987). Consumption and Unemployment. The Quarterly Journal of Economics, 102(2):411-428.

Fanelli, J. M. (2002). Growth, Macroeconomic Instability and the crisis of Convertibility in Argentina. ECLAC Review, 77:32-67.

Frankenberg, E., Smith, J. P., and Thomas, D. (2003). Economic Shocks, Wealth, and Welfare. Journal of Human Resources, 38(2):280-321.

Galasso, E. and Ravallion, M. (2004). Social Protection in a Crisis: Argentina's Plan Jefes y Jefas. World Bank Economic Review, 18(3):367-399.

Gong, X. (2011). The Added Worker Effect for Married Women in Australia. Economic Record, 87(278):414-426. 
Haddad, L., Hoddinott, J., and Alderman, H. (1997). Intrahousehold Resource Allocation in Developing Countries: Models, Methods, and Policy. International Food Policy Research Institute (IFPRI), Johns Hopkins University Press.

Hardoy, I. and Schoene, P. (2013). Displacement and Household Adaptation: Insured by the Spouse or the State? Journal of Population Economics, pages 1-21.

Harkness, S. and Evans, M. (2011). The Employment Effects of Recession on Couples in the UK: Women's and Household Employment Prospects and Partners' Job Loss. Journal of Social Policy, 40(4):675-693.

Heckman, J. J. and Macurdy, T. E. (1980). A Life Cycle Model of Female Labour Supply. The Review of Economic Studies, 47(1):47-74.

Jacoby, H. G. and Skoufias, E. (1997). Risk, Financial Markets, and Human Capital in a Developing Country. The Review of Economic Studies, 64(3):311-335.

Kaplan, G. (2012). Moving Back Home: Insurance against Labor Market Risk. Journal of Political Economy, 120(3):446-512.

Killingsworth, M. R. and Heckman, J. J. (1986). Female Labor Supply: A Survey. Handbook of labor economics, 1:103-204.

Kinsey, B., Burger, K., and Gunning, J. W. (1998). Coping with Drought in Zimbabwe: Survey Evidence on Responses of Rural Households to Risk. World Development, 26(1):89-110.

Klasen, S. and Pieters, J. (2012). Push or Pull? Drivers of Female Labor Force Participation during India's Economic Boom. Discussion Paper 6395, IZA.

Kochar, A. (1999). Smoothing Consumption by Smoothing Income: Hours-of-Work Responses to Idiosyncratic Agricultural Shocks in Rural India. Review of Economics and Statistics, 81(1):50-61.

Kohara, M. (2010). The response of Japanese Wives Labor Supply to Husbands Job Loss. Journal of Population Economics, 23(4):1133-1149.

Krueger, F. (1998). Taking Advantage of Rural Assets as a Coping Strategy for the Urban Poor: the Case of Rural-urban interrelations in Botswana. Environment and Urbanization, 10(1):119-134.

Lim, J. Y. (2000). The Effects of the East Asian Crisis on the Employment of Women and Men: The Philippine Case. World Development, 28(7):1285-1306. 
Lokshin, M. M. and Yemtsov, R. (2004). Household Strategies of Coping with Shocks in Post-crisis Russia. Review of Development Economics, 8(1):15-32.

Lundberg, S., Pollak, R., and Wales, T. (1997). Do Husbands and Wives Pool their Resources? Evidence from the UK Child Benefit. Journal of Human Resources, 32:463480.

MaCurdy, T. (1985). Longitudinal Analysis of Labor Market Data, chapter Interpreting Empirical Models of Labor Supply in a Life Cycle Setting. Cambridge University Press, Cambridge.

MaCurdy, T. E. (1981). An Empirical Model of Labor Supply in a Life-Cycle Setting. Journal of Political Economy, 89(6):1059-1085.

McKenzie, D. and Schargrodsky, E. (2011). Buying less but shopping more: the use of nonmarket labor during a crisis. Economia, 11(2):1-35.

McKenzie, D. J. (2004). Aggregate Shocks and Urban Labor Market Responses: Evidence from Argentina's Financial Crisis. Economic Development and Cultural Change, $52(4): 719-758$.

Mincer, J. (1962). Aspects of Labor Economics, chapter Labor Force Participation of Married Women, pages 63 - 97. Princeton University Press.

Ministerio del Trabajo, E. y. S. S. . (2005). Diagnostico sobre la situación laboral de las mujeres. Technical report, MTEySS.

Mohapatra, S., Joseph, G., and Ratha, D. (2012). Remittances and Natural Disasters: Ex-post Response and Contribution to Ex-ante Preparedness. Environment, Development and Sustainability, 14(3):365-387.

Starr, M. A. (2013). Gender, Added-Worker Effects, and the 2007-2009 Recession: Looking within the Household. Review of Economics of the Household, pages 1-27.

Stephens, M. J. (2002). Worker Displacement and the Added Worker Effect. Journal of Labor Economics, 20(3):504-537.

Stock, J. H. and Yogo, M. (2002). Testing for Weak Instruments in Linear IV Regression. NBER Technical Working Papers 0284, National Bureau of Economic Research, Inc.

Wooldridge, J. M. (2002). Econometric Analysis of Cross Section and Panel Data. MIT Press, Cambridge, Massachusetts. 
Woytinsky, W. S. (1940). Additional Workers and the Volume of Unemployment in the Depression. Pamphlet Series 1, Washington: Social Science Research Council, Committee on Social Security.

Yang, D. (2008). International Migration, Remittances and Household Investment: Evidence from Philippine Migrants Exchange Rate Shocks. The Economic Journal, 118(528):591-630. 


\section{Appendix}

TABLE 14 - Construction of the instrumental variables, based on 2002 shock asymetry between household head sectors: primary and secondary sectors

\begin{tabular}{|c|c|c|c|c|c|c|c|c|}
\hline & \multirow[t]{2}{*}{ Prim } & \multicolumn{7}{|c|}{ Goods } \\
\hline & & Alim & Text & Chem & Metal & Other & Gas & Constr \\
\hline \multirow[t]{2}{*}{$\operatorname{Shock}(2002=1)$} & $-0.437^{*}$ & $-0.413^{*}$ & -0.304 & $-0.623^{*}$ & $-0.847^{*}$ & $-0.831^{*}$ & $-0.310^{*}$ & $-1.027^{*}$ \\
\hline & $(0.145)$ & $(0.112)$ & $(0.199)$ & $(0.170)$ & $(0.144)$ & $(0.131)$ & $(0.100)$ & $(0.080)$ \\
\hline \multirow[t]{2}{*}{ Constant } & $5.913^{*}$ & $5.449^{*}$ & $5.483^{*}$ & $6.226^{*}$ & $5.861^{*}$ & $5.661^{*}$ & $6.507^{*}$ & $4.769^{*}$ \\
\hline & $(0.091)$ & $(0.068)$ & $(0.117)$ & $(0.107)$ & $(0.087)$ & $(0.077)$ & $(0.061)$ & $(0.049)$ \\
\hline \multirow[t]{3}{*}{ Observations } & 594 & 585 & 282 & 253 & 690 & 723 & 287 & 3291 \\
\hline & Prim & \multicolumn{7}{|c|}{ Goods } \\
\hline & & Alim & Text & Chem & Metal & Other & Gas & Constr \\
\hline \multicolumn{9}{|l|}{$I V 1$} \\
\hline Exposed sector ${ }^{a}$ & 0 & 0 & 0 & 1 & 1 & 1 & 0 & 1 \\
\hline \multicolumn{9}{|l|}{$I V 2$} \\
\hline Exposure intensity ${ }^{b}$ & -0.437 & -0.413 & -0.304 & -0.623 & -0.847 & -0.831 & -0.310 & -1.027 \\
\hline
\end{tabular}

Notes: $* \mathrm{p}<0.1,{ }^{* *} \mathrm{p}<0.05,{ }^{* * *} \mathrm{p}<0.01$. Standard errors in parentheses, clustered at the individual level. 


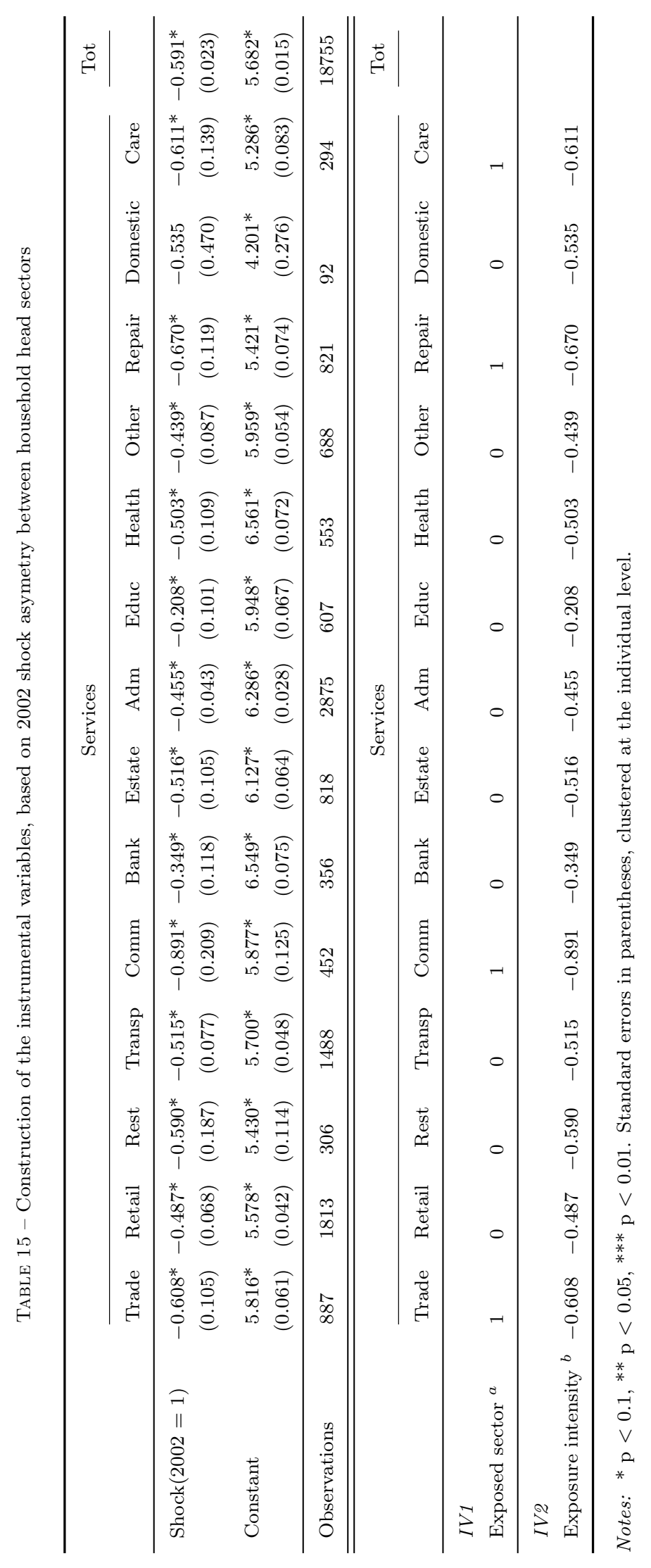

